MICHA£ SŁOMSKI

Instytut Historii Polskiej Akademii Nauk

\title{
SIEĆ MIAST KOŚCIELNYCH ZIEM POLSKICH KORONY W XVI WIEKU. PRZYCZYNEK DO PROBLEMATYKI ${ }^{1}$
}

Zarys treści: Artykuł dotyczy zagadnienia sieci miast, które w XVI w. należały do instytucji kościelnych z ziem polskich. Omówione zostały kwestie własnościowe, udanych i nieudanych inicjatyw lokacyjnych w XVI w. oraz uwarunkowania wpływajace (lub nie) na rozwój i znaczenie ośrodków miejskich. W aneksie wypisano wszystkie miasta należące do instytucji kościelnych wedle stanu z około 1600 r. wraz z podziałem na konkretne instytucje. Załączono także dwie mapy ukazujące własność kościelną pod koniec XVI w. na terenie wszystkich ziem polskich Korony oraz w Wielkopolsce.

The content outline: The paper focuses on the issue of towns in the Polish territory which belonged to ecclesiastical institutions in the $16^{\text {th }}$ century. It discusses the matters of ownership, successful and failed foundation initiatives in the $16^{\text {th }}$ century, and conditions influencing (or not) the development and importance of urban centres. The Annex to this paper contains a list of all ecclesiastical towns as of ca. 1600, sorted by the institution they belonged to. Two maps annexed to the paper present, respectively, ecclesiastical property in the entire territory of the Crown at the end of the $16^{\text {th }}$ century and ecclesiastical property in Greater Poland in the same period.

Słowa kluczowe: sieć miejska, Kościół, miasto, biskup, klasztor, katedra, kolegiata

Keywords: urban network, the Church, town, bishop, monastery, cathedral, collegiate church

Nie powstało do tej pory opracowanie sieci miast kościelnych w Koronie w XVI w. Pisano o nich zazwyczaj na marginesie całościowych ujęć

${ }^{1} \mathrm{~W}$ publikacji wykorzystano materiały zebrane podczas realizacji projektu „Atlas historyczny Polski. Wielkopolska w drugiej połowie XVI w.” (11H 11 004080) finansowanego z Narodowego Programu Rozwoju Humanistyki. 
dotyczących sieci miejskich poszczególnych obszarów dawnej Polski² Wyjątkowo jedynie zwracano uwagę na miasta należące do instytucji kościelnych jednego, określonego typu ${ }^{3}$. Niniejszy tekst będzie jedynie przyczynkiem do obszernego zagadnienia funkcjonującej na ziemiach polskich Korony sieci miast należących do instytucji kościelnych $\mathrm{w}$ XVI w. ${ }^{4} \mathrm{Z}$ racji szerokiego zakresu geograficznego będę się wspierał przede wszystkim ustaleniami literatury, gdyż podjęcie dokładniejszych badań wymaga bardziej szczegółowych studiów nad każdym z miast oraz nad rozwojem sieci miejskiej XVI-wiecznego państwa polskiego. Z jednej strony będę chciał przyjrzeć się stanowi liczbowemu miast kościelnych, uwzględnić dynamikę zmian i rozwoju tej kategorii własności, skrótowo przekazując informacje o inicjatywach lokacyjnych poszczególnych instytucji oraz o ewentualnych zamianach bądź zakupach miast. Nieco ogólniejsze wiadomości prezentuję w części drugiej tekstu, w której podejmuję próby obserwacji pewnych zjawisk - wielkości miast czy czynników decydujących o przedsięwzięciu działań zmierzających do założenia nowych ośrodków. W końcu, bardzo krótko, postaram się usytuować omawiane miasta na tle ziemskich majątków kościelnych ${ }^{5}$.

${ }^{2}$ Zob. nr KHKM poświęcony sieci miejskiej na ziemiach polskich w XIII-XVII w. (t. 28, 1980, nr 3) czy monografie poszczególnych regionów bądź dzielnic.

${ }_{3}^{3}$ D. Karczewski, Rozwój sieci miast klasztornych w Polsce do połowy XVI wieku, $\mathrm{w}$ : Klasztor $w$ mieście średniowiecznym $i$ nowożytnym. Materiaty $z$ międzynarodowej konferencji naukowej zorganizowanej $w$ Turawie $w$ dniach 6-8 V 1999 r. przez Instytut Historii Uniwersytetu Opolskiego i Instytut Historyczny Uniwersytetu Wrocławskiego, red. M. Derwich, A. Pobóg-Lenartowicz, Wrocław-Opole 2000, s. 137-150.

${ }^{4} \mathrm{~W}$ czasie konferencji starałem się przedstawić miasto kościelne jako centrum klucza dóbr. Temat jednak okazał się zbyt obszerny, by zaprezentować go w komunikacie. Tematyka niniejszej pracy została ograniczona do przedstawienia sieci miast kościelnych na ziemiach polskich w XVI w. W swoich rozważaniach pominąłem Warmię, stanowiąca dominium biskupów warmińskich. Istniało tam aż 13 miast kościelnych, należących do biskupów warmińskich oraz tamtejszej kapituły katedralnej: Barczewo, Biskupiec, Bisztynek, Braniewo-Stare Miasto, Braniewo-Nowe Miasto, Dobre Miasto, Frombork, Jeziorany, Lidzbark, Olsztyn, Orneta, Pieniężno, Reszel; A. Szorc, Dominium warmińskie 1243-1772. Przywilej i prawo chetmińskie na tle ustroju Warmii, Olsztyn 1990, s. 256-269. Pominięcie Warmii wynika z metodologii prac nad Atlasem historycznym Polski - została ona pominięta przez M. Biskupa z powodu niedostatecznej podstawy źródłowej, służącej do zrekonstruowania osadnictwa na tym terenie w drugiej połowie XVI w.; Prusy Królewskie w drugiej połowie XVI wieku, oprac. M. Biskup, współpr. L. Koc, Warszawa 1961 (Atlas Historyczny Polski. Seria B: Mapy Przeglądowe, 1), s. 10.

${ }^{5}$ Uzupełnieniem treści prezentowanych w artykule będzie publikacja materiałów statystycznych do miast wielkopolskich w XVI w. w formie przestrzennej bazy danych na witrynie Atlasfontium.pl. 
Pod koniec XVI w. na terenie ziem polskich Korony wyłączną własność kościelna stanowiło 101 miast $^{6}$. Cztery miasta podzielone były między dwie instytucje kościelne: Czerwińsk (tamtejszy klasztor Kanoników Regularnych i biskup płocki), Skarbimierz (kolegium wikariuszy katedry krakowskiej i prepozyt skarbimierski), Skrzynno (cystersi sulejowscy i pleban skrzynecki ${ }^{7}$ oraz podgnieźnieńskie Grzybowo (gnieźnieńskie klasztory Bożogrobców i Klarysek ${ }^{8}$ ). Własnością trzech innych miast - Nasielska, Jędrzejewa i Toporowa - instytucje kościelne dzieliły się ze szlachtą ${ }^{9}$.

${ }^{6} \mathrm{~W}$ analizie pominąem podpoznańskie Piotrowo, należące do poznańskiej kapituły katedralnej. Pierwsze określenie Piotrowa mianem oppidum pochodzi z 1584 r., ze źródła wytworzonego przez kancelarię kapituły poznańskiej, przywilej lokacyjny miasta wystawiony został w 1602 r. Wydaje się, że określenie Piotrowa miastem wynikało z ogólnego rozwoju całej aglomeracji poznańskiej w drugiej połowie XVI w. W tym okresie Piotrowo stanowiło jeszcze raczej przedmieście Poznania niż osobna jednostkę miejska. Kwestia ta wymaga jednak dokładniejszych badań; zob. Z. Kulejewska-Topolska, Nowe lokacje miejskie w Wielkopolsce od XVI do końca XVIII wieku. Studium historyczno-prawne, Poznań 1964, s. 9 i przyp. 39, s. 12, gdzie inne wzmianki źródłowe o Piotrowie ze źródeł kapituły poznańskiej.

${ }^{7}$ Feliks Kiryk (tenże, Skrzynno Opackie i Skrzynno Plebańskie - miasta bliźniacze $i$ konkurencyjne (XIII-XVIII wiek), w: Narodziny Rzeczypospolitej. Studia z dziejów średniowiecza i czasów wczesno nowożytnych, t. 1, red. W. Bukowski, T. Jurek, Kraków 2012, s. 597-627) traktuje obie części Skrzynna jako odrębne jednostki osadnicze.

${ }^{8}$ D. Karczewski, dz. cyt., s. 139-140.

9 Przynależność własnościową miast i osad opracowano na podstawie: M. Biskup, A. Tomczak, Mapy województwa pomorskiego w drugiej połowie XVI w. I. Rozmieszczenie własności ziemskiej, II. Sieć parafialna, Toruń 1955; M. Biskup, Rozmieszczenie własności ziemskiej województwa chetmińskiego $i$ malborskiego $w$ drugiej połowie XVI w. (mapa i materiaty), Torun 1957; Stownik historyczno-geograficzny ziemi chetmińskiej w średniowieczu, oprac. K. Porębska, współpr. M. Grzegorz, red. M. Biskup, Wrocław 1971; Z. Guldon, Rozmieszczenie wtasności ziemskiej na Kujawach w II połowie XVI w., Toruń 1964; tenże, Mapy ziemi dobrzyńskiej $w$ drugiej połowie XVI $w$. I. Podziały administracyjne, II. Rozmieszczenie własności ziemskiej, Toruń 1967; Polska XVI wieku pod względem geograficzno-statystycznym, t. 5: Mazowsze, oprac. A. Pawiński, Warszawa 1895 (Źródła Dziejowe, 16), s. 126-133, 316-317, 394-396, 406-408; W. Pałucki, Przynależność własnościowa osad, w: Mazowsze w drugiej połowie XVI wieku, red. W. Pałucki, cz. 2: Komentarz. Indeksy, Warszawa 1973 (Atlas Historyczny Polski. Mapy Szczegółowe XVI wieku, 7); Stownik historyczno-geograficzny ziemi wyszogrodzkiej w średniowieczu, oprac. A. Wolff, A. Borkiewicz-Celińska, Wrocław 1971; Stownik historyczno-geograficzny województwa płockiego w średniowieczu, oprac. A. Borkiewicz-Celińska, z. 1-2, Wrocław 1980-1981, z. 3-4, Warszawa 1998-2000; Stownik historyczno-geograficzny ziemi warszawskiej w średniowieczu, oprac. A. Wolff, K. Pacuski, do druku przyg. M. Piber-Zbieranowska, A. Salina, red. T. Jurek, Warszawa 2013; Województwo lubelskie w drugiej połowie XVI wieku, oprac. S. Wojciechowski, Warszawa 1966 (Atlas Historyczny Polski. Mapy Szczegółowe XVI wieku, 3); W. Pałucki, Przynależność wtasnościowa osad, w: Województwo sandomierskie w drugiej 
Tabela 1 zawiera informacje o liczbie miast kościelnych w granicach poszczególnych województw Korony w drugiej połowie XVI w. oraz ich procentowym udziale $\mathrm{w}$ sieci miejskiej tych jednostek administracyjnych.

Najwięcej miast kościelnych w tym okresie było na terenie woj. sandomierskiego. W jego granicach znajdowało się 25 ośrodków. Więcej niż 10 istniało w woj. kaliskim $(14,5)$, poznańskim (13), krakowskim (11) i mazowieckim $(10,5)$. Kilka leżało w woj. sieradzkim z ziemią wieluńską $(7,5)$, rawskim (5), chełmińskim i łęczyckim (po 4), w woj. brzeskim kujawskim i na terenie księstwa siewierskiego (po 3), 2 na terenie woj. inowrocławskiego i lubelskiego, $1 \mathrm{w}$ ziemi dobrzyńskiej i woj. płockim. Poza woj. chełmińskim brakuje miejskich ośrodków kościelnych w pozostałych województwach Prus Królewskich - pomorskim i malborskim ${ }^{10}$ (poza Warmia) oraz na terenie przyłączonego w 1569 r. Podlasia.

połowie XVI wieku, red. W. Pałucki, cz. 2: Komentarz. Indeksy, Warszawa 1993 (Atlas Historyczny Polski. Mapy Szczegółowe XVI wieku, 2), s. 91-94; A. Dunin-Wąsowicz, Większe kompleksy dóbr $w$ posiadaniu instytucji kościelnych $w$ woj. sandomierskim $w$ ostatniej ćwierci XVI w., w: tamże, s. 112-113; K. Chłapowski, Przynależność własnościowa osiedli i Aneks II. Dobra w posiadaniu instytucji kościelnych w końcu XVI w., w: Województwo krakowskie $w$ drugiej połowie XVI wieku, red. H. Rutkowski, cz. 2: Komentarz. Indeksy, Warszawa 2008 (Atlas Historyczny Polski. Mapy Szczegółowe XVI wieku, 1), s. 83-94, 100-106; K. Chłapowski, A. Dunin-Wasowiczowa, Przynależność własnościowa osiedli i Aneks II: Dobra w posiadaniu instytucji kościelnych $w$ końcu XVI wieku, w: Województwo sieradzkie i województwo tęczyckiej $w$ drugiej połowie XVI wieku, red. S. Trawkowski, cz. 2: Komentarze. Indeksy, Warszawa 1998 (Atlas Historyczny Polski. Mapy Szczegółowe XVI wieku, 5), s. 58-64, 67-70; Polska XVI wieku pod względem geograficzno-statystycznym, t. 6, cz. 2: Podlasie, oprac. A. Jabłonowski, Warszawa 1909 (Źródła Dziejowe, 17/2), Warszawa 1909, s. 122-125; A. Laszuk, Zaścianki i królewszczyzny. Struktura własności ziemskiej w województwie podlaskim $w$ drugiej połowie XVII wieku, Warszawa 1998; J. Topolski, Rozwój latyfundium arcybiskupstwa gnieźnieńskiego od XVI do XVIII wieku, Poznań 1955; W. Sobisiak, Rozwój latyfundium biskupstwa poznańskiego w XVI do XVIII wieku, Poznań 1960; L. Polaszewski, Własność feudalna w województwie kaliskim $w$ XVI wieku, Poznań 1976; U. Piotrkowska, Struktura i rozmieszczenie własności ziemskiej $w$ powiecie kościańskim $i$ ziemi wschowskiej $w$ drugiej połowie XVI wieku, „Rocznik Leszczyński” 1, 1976, s. 207-320; taż, Struktura i rozmieszczenie własności ziemskiej $w$ powiatach poznańskim i wateckim $w$ drugiej potowie XVI wieku, „Studia i Materiały do Dziejów Wielkopolski i Pomorza” 17, 1989, z. 1, s. 5-112; poszczególne tomy Stownika historyczno-geograficzny województwa poznańskiego w średniowieczu, cz. 1, oprac. S. Chmielewski, K. Górska-Gołaska, J. Luciński, Wrocław 1982-1987.

${ }^{10} \mathrm{~W}$ sytuacji tej trzeba widzieć efekt polityki miejskiej książąt pomorskich i przede wszystkim - Krzyżaków oraz stosunku tych ostatnich do instytucji kościelnych posiadających dobra na terenie Pomorza Gdańskiego; zob.: T. Lalik, Regale targowe ksiażat wschodniopomorskich $w$ XII-XIII w., PH, t. 56, 1965, s. 184-189, 193-196; M. Biskup, Rozwój sieci miast pruskich do drugiej połowy XVII w., KHKM, t. 28, 1980, 
Tabela 1. Liczba miast kościelnych w porównaniu do liczby miast królewskich i szlacheckich i procentowy ich udział w całej sieci miejskiej na ziemiach polskich Korony w drugiej połowie XVI w.

\begin{tabular}{|c|c|c|c|c|c|}
\hline \multirow[b]{2}{*}{ Województwo } & \multicolumn{3}{|c|}{$\begin{array}{l}\text { Liczba miast według } \\
\text { charakteru własności }\end{array}$} & \multirow[b]{2}{*}{$\begin{array}{c}\text { wszystkie } \\
\text { miasta }\end{array}$} & \multirow[b]{2}{*}{$\begin{array}{l}\text { procentowy } \\
\text { udzial w sieci } \\
\text { miejskiej }\end{array}$} \\
\hline & królewskie & szlacheckie & duchowne & & \\
\hline krakowskie & 40 & 22 & 11 & 73 & 15 \\
\hline siewierskie & 0 & 0 & 3 & 3 & 100 \\
\hline sandomierskie & 20 & 57 & 25 & 102 & 24,5 \\
\hline lubelskie & 9 & 25 & 2 & 36 & 5 \\
\hline łęczyckie & 6 & 17 & 4 & 27 & 15 \\
\hline sieradzkie & 16 & 21,5 & 7,5 & 45 & 17 \\
\hline rawskie & 10 & 8 & 5 & 23 & 22 \\
\hline płockie & 4 & 11 & 1 & 16 & 6 \\
\hline mazowieckie & 36 & 21,5 & 10,5 & 68 & 15 \\
\hline poznańskie & 15 & 38 & 13 & 66 & 20 \\
\hline kaliskie & 18 & 61,5 & 14,5 & 94 & 15 \\
\hline inowrocławskie & 6 & 2 & 2 & 10 & 20 \\
\hline brzeskie kujawskie & 7 & 3 & 3 & 13 & 23 \\
\hline ziemia dobrzyńska & 5 & 1 & 1 & 7 & 14 \\
\hline chełmińskie & 10 & 0 & 4 & 14 & 28,5 \\
\hline pomorskie & 15 & 0 & 0 & 15 & 0 \\
\hline malborskie & 5 & 0 & 0 & 5 & 0 \\
\hline podlaskie & 12 & 16 & 0 & 28 & 0 \\
\hline Korona & 234 & 304,5 & 106,5 & 645 & 16,5 \\
\hline
\end{tabular}

Źródło: oprac. własne na podstawie danych znajdujących się na stronie Atlasfontium.pl.

Gdy jednak porównać procentowy stosunek do pozostałych miast (królewskich i szlacheckich), znajdujących się w obrębie granic danej jednostki administracyjnej, to największy odsetek ośrodków kościelnych

nr 3, s. 401-412; tenże, Średniowieczna sieć klasztorów w państwie zakonu krzyżackiego, „Zapiski Historyczne” 64, 1999, z. 1, s. 54-56; M. Grzegorz, Struktura administracyjna i wtasnościowa Pomorza Gdańskiego pod rzqdami zakonu krzyżackiego w latach 1309-1454, Warszawa-Poznań-Toruń 1987, s. 164 i tab. 3; tenże, Lokacja miast na Pomorzu Gdańskim w latach 1309-1454 na tle działalności politycznej $i$ gospodarczej oraz administracyjnej zakonu krzyżackiego, w: W kregu stanowych i kulturowych przeobrażeń Europy Pótnocnej w XIV-XVIII wieku, red. Z.H. Nowak, Toruń 1988, s. 48-52. Warto zauważyć, że zorganizowane ostatecznie w 1243 r. biskupstwa pruskie posiadały własne ośrodki miejskie, które w większości znajdowały się na terenie podbijanych przez Krzyżaków Prus. 
znajdował się na terenie woj. chełmińskiego ${ }^{11}$. Na ogólną liczbę 14 miast 4 stanowiły własność kościelna, co daje współczynnik 28,5\% chełmińskiej sieci miejskiej. Jednak woj. sandomierskie również miało wysoki współczynnik. Na tle 102 miast sandomierskie ośrodki kościelne stanowiły $24,5 \%$. Odsetek równy $20 \%$ lub wyższy można znaleźć również w następujących województwach: brzeskim kujawskim (23\%), rawskim (22\%), poznańskim i inowrocławskim (po 20\%). Ciekawie wypada porównanie ostatnich dwóch z wymienionych województw. Choć różnica $\mathrm{w}$ liczbie miast jest znaczna $(13 \mathrm{w}$ woj. poznańskim, $2 \mathrm{w}$ inowrocławskim), to jednak rzadsza sieć miejska i mniejsza powierzchnia woj. inowrocławskiego powoduje, że współczynnik procentowy jest taki sam jak w rozleglejszym i lepiej zurbanizowanym poznańskim. Następne w kolejności, w zakresie 14-17\%, były: woj. sieradzkie z ziemią wieluńską (17\%), kaliskie, krakowskie, łęczyckie i mazowieckie (po 15\%) i ziemia dobrzyńska (14\%). Mały udział miast kościelnych był w woj. płockim i lubelskim, odpowiednio 6 i 5\%.

Patrząc całościowo, miasta kościelne stanowiły blisko $17 \%$ wszystkich ośrodków pod koniec XVI w. (106,5 z 645 miast polskich), przy $36 \%$ miast królewskich i $47 \%$ szlacheckich.

Tabela 2 przedstawia stosunek własnościowy miast kościelnych. Zaznaczono w niej podział na własność biskupia, klasztorna, katedralna, kolegiacką i plebańska.

W rękach biskupów znajdowało się 51 miast i połowa kolejnego ${ }^{12}$. Najwięcej, bo aż 13, stanowiło własność arcybiskupów gnieźnieńskich ${ }^{13}$. Niewiele mniej, bo 12, należało do biskupów krakowskich. 10 miast posiadali biskupi poznańscy, 6,5-płoccy, 5 - włocławscy. Biskup chełmiński miał 3 miasta, po 1 zaś mieście biskupi chełmski ${ }^{14}$ i przemyski.

${ }^{11}$ Pomijam tu przypadek księstwa siewierskiego, w którym wszystkie 3 funkcjonujace tam miasta (Siewierz, Czeladź, Koziegłowy) stanowiły własność biskupów krakowskich.

${ }^{12} \mathrm{Na}$ początku XVI w. swoje miasta posiadali również biskupi lubuscy, jednak do końca pierwszej dekady XVI w. miasta te zmieniły przynależność własnościowa; zob. w dalszej części pracy.

${ }_{13}$ Prawie przez cały XVI w. do arcybiskupów należało też miasto Kwieciszewo, przekazane w 1591 r. kapitule gnieźnieńskiego przez Stanisława Karnkowskiego (J. Topolski, Rozwój latyfundium..., s. 51, 104) - uwzględniając XVI w. przekrojowo, należy przyjąć, że arcybiskupi byli właścicielami 14 miast.

${ }^{14}$ Do miast stanowiących własność kościelna wliczam Białą (Białą Rawska), od 1510 do 1600 r. znajdująca się z nadania Aleksandra Jagiellończyka w rękach biskupów chełmskich; A. Swieżawski, Biała Rawska w średniowieczu, „Rocznik Łódzki” 14 (17), 1970, s. 380-381; W. Pałucki, Przynależność wtasnościowa osad, w: Mazowsze $w$ drugiej połowie XVI wieku..., s. 93-94 i przyp. 34 na s. 94. 
Tabela 2. Podział własnościowy miast pomiędzy instytucjami kościelnymi na ziemiach polskich Korony w XVI w.

\begin{tabular}{|c|c|c|c|c|c|c|}
\hline \multirow[b]{2}{*}{ Województwo } & \multicolumn{5}{|c|}{ Własność miast według charakteru instytucji kościelnej } & \multirow[b]{2}{*}{ razem } \\
\hline & biskupstwa & \begin{tabular}{c|} 
kapituły \\
katedralne
\end{tabular} & \begin{tabular}{c|} 
kapituły \\
kolegiackie
\end{tabular} & klasztory & pleban & \\
\hline krakowskie & 3 & 0,5 & 0,5 & 7 & 0 & 11 \\
\hline sandomierskie & 10 & 0 & 1 & 13,5 & 0,5 & 25 \\
\hline lubelskie & 1 & 0 & 0 & 1 & 0 & 2 \\
\hline księstwo siewierskie & 3 & 0 & 0 & 0 & 0 & 3 \\
\hline łęczyckie & 3 & 0 & 0 & 1 & 0 & 4 \\
\hline sieradzkie & 4 & 2,5 & 0 & 1 & 0 & 7,5 \\
\hline rawskie & 3 & 0 & 0 & 2 & 0 & 5 \\
\hline płockie & 1 & 0 & 0 & 0 & 0 & 1 \\
\hline mazowieckie & 5,5 & 0 & 1 & 4 & 0 & 10,5 \\
\hline poznańskie & 6 & 2 & 0 & 5 & 0 & 13 \\
\hline kaliskie & 5 & 1,5 & 0 & 8 & 0 & 14,5 \\
\hline inowrocławskie & 1 & 0 & 0 & 1 & 0 & 2 \\
\hline brzeskie kujawskie & 2 & 0 & 0 & 1 & 0 & 3 \\
\hline ziemia dobrzyńska & 1 & 0 & 0 & 0 & 0 & 1 \\
\hline chełmińskie & 3 & 1 & 0 & 0 & 0 & 4 \\
\hline pomorskie & 0 & 0 & 0 & 0 & 0 & 0 \\
\hline malborskie & 0 & 0 & 0 & 0 & 0 & 0 \\
\hline podlaskie & 0 & 0 & 0 & 0 & 0 & 0 \\
\hline Korona & 51,5 & 7,5 & 2,5 & 44,5 & 0,5 & 106,5 \\
\hline
\end{tabular}

Źródło: oprac. własne na podstawie danych znajdujących się na stronie Atlasfontium.pl.

Drugim w kolejności właścicielem miast były instytucje zakonne. Do 27 klasztorów należały 43 ośrodki (jeden podzielony między dwa zakony) oraz trzy części pozostałych. Aż 5 było własnością benedyktynów tynieckich. Dużo miast -4 - stanowiło własność kanoników regularnych z Trzemeszna. Po 3 posiadali benedyktyni lubińscy i cystersi wąchoccy. Do cystersów sulejowskich należały 2 miasta i połowa kolejnego. Po 2 ośrodki były własnością 5 klasztorów: benedyktynów płockich i sieciechowskich, bożogrobców miechowskich, cystersów lądeckich, klarysek krakowskich. Półtora miasta miały klaryski gnieźnieńskie. Benedyktyni mogileńscy i świętokrzyscy, cystersi z Bledzewa, Jędrzejowa, Koprzywnicy, Koronowa, Przemętu i Wagrowca, 
kanonicy regularni z Mstowa, klaryski sądeckie, norbertanie hebdowscy oraz norbertanki buskie, płockie i strzelneńskie dysponowali jednym ośrodkiem miejskim. Części w dwóch miastach należały do kanoników regularnych z Czerwińska, bożogrobcy gnieźnieńscy zaś mieli połowę jurydyki Grzybowo ${ }^{15}$.

Trzeba jednak zauważyć, że większość miast klasztornych była niewielka. Chociaż kanonicy regularni z Trzemeszna posiadali cztery miasta, to tylko Trzemeszno było stosunkowo prężnym i silnym ośrodkiem. Pozostałe trzy to niewielkie mieściny. W rejestrach poborowych woj. kaliskiego z drugiej połowy XVI w. Gąsawa i Wylatowo nie płaciły nawet szosu. Miały też niski współczynnik innego kryterium, z którego można ostrożnie korzystać, starając się określić wielkość miast, mianowicie liczbę rzemieślników, od których zapłacono podatek. W Gąsawie oddawano należności od trzech do maksymalnie siedmiu rzemieślników, w Wylatowie najwięcej razy płacono od czterech rzemieślników, co stanowi $\mathrm{w}$ tym przypadku również maksymalną wartośćc ${ }^{16}$. Kazimierz (woj. łęczyckie) z kolei w rejestrze poborowym z $1576 \mathrm{r}$. wymieniony został wśród $\mathrm{wsi}^{17}$. Dla porównania w Trzemesznie rejestry notuja pobór od 25 do 51 rzemieślników. Pozwala to sytuować Trzemeszno wśród największych miast kościelnych w woj. kaliskim ${ }^{18}$. Z trzech miast cystersów wąchockich Wierzbica i Waśniów w XVI w. były niewielkimi ośrodkami, nawet w porównaniu z Wąchockiem, najprężniejszym miastem tejże wspólnoty ${ }^{19}$.

Wydaje się, że częściej na silniejsze ośrodki miejskie wyrastały te, które były jedynymi miastami danego klasztoru (Mstów, Jędrzejów,

${ }^{15}$ Zob. D. Karczewski, dz. cyt., passim. Literatura dotycząca uposażenia poszczególnych klasztorów i ich dziejów gospodarczych jest ogromna. Zazwyczaj jednak analizy kończą się na XV w. i rzadko kiedy badacze wchodzą w wiek XVI. Por. z historiografia zachodnioeuropejską: M. Derwich, Klasztor a miasto $w$ średniowieczu $w$ historiografii europejskiej. Próba podsumowania, w: Klasztor w mieście..., s. 21-50, zwł. s. 36-38.

${ }^{16}$ Wykorzystano dane dostępne w witrynie Atlasfontium.pl: Atlas historyczny Polski. Rejestry poborowe województwa kaliskiego w XVI wieku, red. M. Słoń, „Atlas Źródeł i Materiałów do Dziejów Dawnej Polski” 2, 2015.

${ }_{17}$ Polska XVI wieku pod względem geograficzno-statystycznym, t. 2: Wielkopolska, oprac. A. Pawiński, Warszawa 1883 (Źródła Dziejowe, 13), s. 54.

18 Uwzględniając największą liczbę rzemieślników, od których płacono podatek w drugiej połowie XVI w., Trzemeszno znajdowało się za Żninem (132 rzemieślników), Słupca (128), Wagrowcem (125) i tuż za Mogilnem (55). O wykorzystaniu tego kryterium do określania znaczenia miast zob. artykuł M. Słonia w niniejszym tomie.

${ }^{19}$ L. Stępkowski, Z dziejów miast opactwa wachockiego w XIII-XIX w. (do 1819 r.), w: Z dziejów opactwa cystersów w Wachocku. Materiaty z sesji naukowej 1991 rok, red. A. Massalski, D. Olszewski, Kielce 1993, s. 28-31. 
Koronowo czy wspomniane Mogilno), choć trudno upatrywać w tym ścisłej reguły. Ważny był też czas lokowania osad: przeniesiony na prawo miejskie w XV w. Bledzew nie rozwiną się do ośrodka znacznych rozmiarów, jak wymienione wcześniej, a lokowane w XIII-XIV w. osady ${ }^{20}$.

Do czterech kapituł katedralnych należało siedem miast i pół kolejnego: dwa całe i część kolejnego do kapituły krakowskiej, jedno całe i części w dwóch do kapituły gnieźnieńskiej, również dwa do kapituły poznańskiej i jedno do kapituły chełmińskiej ${ }^{21}$. Własnych miast nie miały kapituły katedralne z Włocławka i Płocka.

Z kolei własność trzech kapituł kolegiackich stanowiły dwa ośrodki i część kolejnego. W całości swoje miasta posiadały kolegiaty w Sandomierzu i Warszawie, pół Skarbimierza należało do miejscowego prepozyta. Jako wyjątek występuje pleban ze Skrzynna, należącego w części do cystersów z Sulejowa, a częściowo do wspomnianego duchownego ${ }^{22}$.

Na początku XVI w. sieć miejska w Koronie była już mocno rozbudowana. Nie oznacza to jednak, że na przestrzeni XVI stulecia nie podejmowano próby nowych lokacji ${ }^{23}$. Najwięcej takich działań było przejawem inicjatywy szlacheckiej ${ }^{24}$, jednak instytucje kościelne również nie pozostawały bierne na tym polu.

${ }^{20}$ K. Górska-Gołaska, Bledzew, w: Stownik historyczno-geograficzny województwa poznańskiego w średniowieczu..., cz. 1, s. 57-58.

${ }^{21}$ Jako ośrodki miejskie traktuję Jędrzejewo, zwane też Cierpięgami lub Jelenia Głowa, oraz Grzybowo (stanowiące własność dwóch gnieźnieńskich konwentów: bożogrobców i klarysek), w gruncie rzeczy stanowiące jurydykę w Gnieźnie, posiadające jednak w różnym stopniu wykształconą organizację władzy i funkcji miejskich; J. Topolski, Gniezno miejscem wielkich jarmarków, w: Dzieje Gniezna, red. J. Topolski, Warszawa 1965, s. 260. Problem jurydyk gnieźnieńskich pozostaje nieprzebadany. Jako osobne jednostki osadnicze pojawiają się one również w rejestrach poborowych z drugiej połowy XVI w.; np. AGAD, Archiwum Skarbu Koronnego, dział I, t. 12, k. 645v; dział I, t. 13, k. 616. Wliczam tu też Skarbimierz, którego połowa należała do wikariuszy katedralnych z Krakowa.

${ }^{22}$ W. Pałucki, Przynależność własnościowa osad, w: Województwo sandomierskie $w$ drugiej połowie XVI wieku..., s. 94 i przyp. 40.

${ }^{23}$ Według obliczeń Marii Boguckiej w XVI w. przyrost liczby osiedli na ziemiach Korony (bez Wołynia, Podola i Ukrainy, ale z Rusią Czerwona, której nie uwzględniam w tekście) w stosunku do XV w. wynosił 25\%; M. Bogucka, H. Samsonowicz, Dzieje miast $i$ mieszczaństwa $w$ Polsce przedrozbiorowej, Wrocław 1986, s. 331. Andrzej Wyrobisz wskazał na podobny procent lokacji nowożytnych (XVI- i XVII-wiecznych) na terenach Wielkopolski, Małopolski i Mazowsza - wynosił on ok. 25\% ogólnej liczby miast pod koniec XVII w.; tenże, Rola miast prywatnych $w$ Polsce $w$ XVI i XVII wieku, PH, t. 65 , 1974, z. 1, s. 20-23.

${ }^{24}$ Zob. ustalenia: R. Szczygieł, Lokacje miast w Polsce XVI wieku, Lublin 1989, s. 90. Według obliczeń tego badacza lokacje szlacheckie stanowiły 78,4\% wszystkich inicjatyw, przy 15,4-procentowym udziale króla i ledwie 6,2-procentowym Kościoła. 
W XVI w. biskupi płoccy lokowali Brok, Wyszków i Andrzejów (odpowiednio w latach: 1501,1502 i 1534) $)^{25}$, biskupi poznańscy - Stoczek $(1546)^{26}$, biskupi krakowscy - Daleszyce $(1569 / 1570)^{27}$. Na początku XVI w. ostatecznie doszło do lokacji Rzgowa przez krakowską kapitułę katedralną ${ }^{28}$. Jedyną udaną inicjatywą zakonną była lokacja Puchaczowa przez benedyktynów sieciechowskich w $1527 \mathrm{r.}^{29}$

Nie wszystkie jednak próby były udane. Nie doszło do przekształcenia w ośrodki miejskie wsi Chełmno nad Nerem $^{30}$ i Kozieniec ${ }^{31}$ w dobrach arcybiskupa gnieźnieńskiego, Ciążenia biskupów poznańskich ${ }^{32}$, Babic koło zamku Lipowiec biskupów krakowskich ${ }^{33}$, Kochowa czerwińskich kanoników regularnych ${ }^{34}$, wsi Błogie cystersów sulejowskich ${ }^{35}$,

${ }_{25}^{5}$ W.H. Gawarecki, Przywileje, nadania i swobody, przez królów polskich, ksią̇at mazowieckichibiskupówpłockich udzielone miastom województwapłockiego, Warszawa 1828, s. 7-11, 48-51, 266-271; T. Krajewski, Społeczno-gospodarczy rozwój $i$ upadek Broku w XVI-XVII wieku, w: Brok i Puszcza Biała. Przeszłość-środowisko geograficzne, kulturowe i przyrodnicze, Ciechanów 1989, s. 28-31; J. Szczepański, Dzieje Wyszkowa $i$ okolic, Warszawa 1998, s. 21-35; M. Bogucka, H. Samsonowicz, dz. cyt., s. 335.

${ }^{26}$ J. Nowacki, Dzieje archidiecezji poznańskiej, t. 2: Archidiecezja poznańska $w$ granicach historycznych i jej ustrój, Poznań 1964, s. 148; W. Sobisiak, dz. cyt., s. 60; R. Szczygieł, dz. cyt., s. 47, 228. W rejestrach poborowych często było nazywane dalej Sebastianowem; Polska XVI wieku..., t. 5: Mazowsze, s. 248.

${ }^{27}$ R. Szczygieł, dz. cyt., s. 234; F. Kiryk, Lokacje miast biskupich w prepozyturze kieleckiej, w: Pamiętnik świętokrzyski. Studia z dziejów kultury chrześcijańskiej. Praca zbiorowa, Kielce 1991, s. 58-59.

${ }^{28}$ R. Szczygieł, dz. cyt., s. 40-41; M.D. Kowalski, Uposażenie krakowskiej kapituty katedralnej w średniowieczu, Kraków 2000, s. 57-58.

${ }^{29}$ MRPS, cz. 4: Sigismundi I regis tempora complectens (1507-1548), t. 1: Acta cancellariorum 1507-1548, wyd. T. Wierzbowski, Varsoviae 1910, nr 5197; R. Szczygieł, dz. cyt., s. 254-255.

${ }^{30}$ P. Tafiłowski, Jan Easki (1456-1531), kanclerz koronny i prymas Polski, Warszawa 2007, s. 395; Polska XVI wieku..., t. 2: Wielkopolska, s. 51; J. Topolski, Rozwój latyfundium..., s. 82-86; R. Szczygieł, dz. cyt., s. 38-39, 214-215, który dodaje, że Chełmno było nazywane miastem już w czasie spisywania Liber beneficiorum. Badacz ten napisał, że lokacja Chełmna nie udała się z powodu bliskości Łodzi (tamże, s. 214). Informację tę należy oczywiście odnieść do analizowanego przez badacza przed Chełmnem Brusa kapituły krakowskiego (zob. dalej).

${ }^{31}$ R. Szczygieł, dz. cyt., s. 31-32, 209.

32 J. Nowacki, dz. cyt., s. 159; R. Szczygieł, dz. cyt., s. 35-36, 211, który zauważa, że w XVI w. Ciążeń bywał zaliczany do miast w rejestrach poborowych.

${ }^{33}$ F. Kiryk, Lokacje miejskie nieudane, translacje miast i miasta zanikłe $w$ Małopolsce do połowy XVII stulecia, KHKM, t. 28, 1980, nr 3, s. 374.

${ }^{34}$ Tamże; R. Szczygieł, dz. cyt., s. 238. Klasztor w Czerwińsku pozbył się w $1524 \mathrm{r}$. dóbr zorganizowanych koło Kochowa, sprzedajac je staroście chełmskiemu Feliksowi Zielonce; W. Pałucki, Przynależność własnościowa osad, w: Województwo sandomierskie w drugiej połowie XVI wieku..., s. 96.

${ }^{35}$ R. Szczygieł, dz. cyt., s. 233. 
Spotowa cystersów wąchockich ${ }^{36}$, Długosiodła kapituły kolegiackiej w Pułtusku ${ }^{37}$, Nakielnicy prepozyta kolegiaty w Łęczycy ${ }^{38}$ oraz wsi Brus kapituły katedralnej z Krakowa ${ }^{39}$.

Łącznie w XVI w. instytucje kościelne podjęły 17 inicjatyw lokacyjnych. Powodzeniem zakończyło się 7 z nich (41\% prób), 10 zaś (59\%) ostatecznie nie doszło do skutku.

Najwięcej działań podjęli biskupi. Byli oni inicjatorami 9 z 17 poczynań lokacyjnych (53\%). Biskupi płoccy przedsięwzięli trzy inicjatywy, z których wszystkie doszły do skutku. Dwukrotnie próbowali zakładać miasto arcybiskupi gnieźnieńscy, biskupi krakowscy i poznańscy. Ordynariuszom z Poznania i Krakowa udało się założyć po jednym mieście, natomiast próby gnieźnieńskich hierarchów kończyły się niepowodzeniem. Spośród kapituł katedralnych działania lokacyjne podejmowała jedynie kapituła krakowska w swoich dobrach pabianickich, z których jedna się udała, a jedna nie. Działania kapituły stanowiły $12 \%$. Cztery razy $(23,5 \%)$ próbowano założyć miasto $\mathrm{w}$ dobrach należących do instytucji zakonnych. Tylko przekształcenie Puchaczowa doszło do skutku. Żadna z dwóch prób lokacyjnych podjętych przez podmioty związane z kolegiatami (kolegiaty w Pułtusku i prepozyta łęczyckiego) ostatecznie nie została zrealizowana (12\% wszystkich wysiłków).

Za każdym razem wykorzystano lub chciano wykorzystać istniejące już struktury osadnicze do założenia nowego ośrodka miejskiego. Jednym z najsilniej urbanizowanych rejonów XVI-wiecznej Korony było woj. mazowieckie ${ }^{40}$. W tym regionie doszło do powstania aż czterech nowych miast - wszystkich należących do biskupów (płockiego i poznańskiego).

36 Tamże, s. 247.

37 Tamże, s. 47, 222-223; H. Samsonowicz, Dtugosiodto - kariera wsi mazowieckiej $w$ średniowieczu, „Rocznik Mazowiecki” 18, 2006, s. 40-41.

38 R. Szczygieł, dz. cyt., s. 215.

39 Tamże, s. 214. Przyczyną nieudanego przekształcenia Brusa w miasto było zagęszczenie sieci miejskiej w rejonie granicy łęczycko-sieradzkiej. Wydaje się, że ośrodek ten mocniej konkurował o swoja pozycję z Pabianicami i Rzgowem niż z Łodzia, jak uważał R. Szczygieł; zob. też J. Malinowska, Studia osadnicze na obszarze powiatu brzezińskiego do połowy XVI wieku, Torun 2002, s. 21.

${ }^{40}$ Tereny województwa mazowieckiego były intensywnie urbanizowane w XV i XVI w.; S. Pazyra, Studia z dziejów miast na Mazowszu od XIII do poczatków XX wieku, Lwów 1939, s. 77-78; M. Bogucka, H. Samsonowicz, dz. cyt., s. 335-336. Nie traktuję jako nowej lokacji przywileju dla klasztornej części Czerwińska z 1582 r. Miasto funkcjonowało tam zapewne dużo wcześniej, choć rzeczywiście wzmianki o jego istnieniu pochodzą dopiero z XVI w.; zob. H. Wajs, Źródta do dziejów średniowiecznego $i$ wczesnonowożytnego Czerwinska w zbiorach Archiwum Głównego Akt Dawnych w Warszawie, w: Dzieje klasztoru w Czerwinsku, [red. E. Olbromski], Lublin 1997, s. 25-27. 
Jak pokazuje jednak przypadek Długosiodła, nie zawsze podjęta na terenie woj. mazowieckiego lokacja dochodziła do skutku. Stosunkowo licznie reprezentowane są również małopolskie inicjatywy, większość z nich jednak nie została zrealizowana. Warto zauważyć, że wszystkie trzy nieudane próby związane z klasztorami miały miejsce na terenie woj. sandomierskiego. Niemniej jednak, w granicach tego samego województwa biskupom krakowskim udało się założyć nowe miasto. Trzecim regionem w XVI w., w którym instytucje kościelne intensywniej przejawiały dążenia do tworzenia nowych miast, było woj. łęczyckie i pogranicze łęczyckiego z sieradzkim, głównie w okolicach Łodzi.

Chociaż przyczyny nieudanych lokacji mogły zależeć od różnych czynników, to najczęstszym powodem niepowodzenia musiało być względne nasycenie sieci miejskiej, wyrażające się w zbyt małych odległościach między nowo zakładanymi a już istniejacymi miastami. Jednak i od tej reguły można znaleźć wyjątki. Stoczek biskupów poznańskich leżał w odległości $6 \mathrm{~km}$ od Seroczyna, tym niemniej udało mu się przetrwać jako miastu. Zazwyczaj jednak odległość taka okazywała się zbyt bliska. Dlatego zapewne nie udało się kapitule krakowskiej z lokacja Brusa czy arcybiskupowi gnieźnieńskiemu z Chełmnem, położonym zbyt blisko istniejących już miast, które mogły mieć jednak znaczenie tylko na lokalnym terenie.

Obraz zmian w XVI-wiecznej sieci miast kościelnych nie byłby pełny bez informacji dotyczących zamian własnościowych, jakie zaszły w tym stuleciu. Na początku wieku na terenie Korony dwa miasta - Kazimierz Biskupi (woj. kaliskie) i Opatów (woj. sandomierskie) posiadali biskupi lubuscy. Oba zostały sprzedane szlachcie, Kazimierz Biskupi w 1504 r. Lubrańskim, Opatów zaś w 1518 r. Szydłowieckim $^{41}$. W 1512 r. biskup płocki Erazm Ciołek dokonał zamiany z królem Zygmuntem Starym. Za znajdujący się w woj. lubelskim klucz kocki wraz z miastem Kockiem otrzymał od króla miasto Raciąż, położone w woj. płockim ${ }^{42}$. W drugiej połowie XVI w. kapituła gnieźnieńska nabyła połowę Toporowa w ziemi wieluńskiej (lata 70. XVI w.), w 1591 r. zaś arcybiskup Stanisław Karnkowski przekazał jej Kwieciszewo ${ }^{43}$.

${ }^{41}$ K. Górska-Gołaska, Kazimierz Biskupi w średniowieczu, w: Dzieje Kazimierza Biskupiego, cz. 1: Monografia, red. Z. Chodyła, Kazimierz Biskupi-Konin 2001, s. 65-66; A. Weiss, Biskupstwo lubuskie, Lubusz, lubuska ziemia, w: Kapituła kolegiacka $w$ Opatowie w 800-lecie istnienia, red. M. Spociński, Z. Pałubska, Opatów 2007, s. 47.

${ }_{2}$ Stownik historyczno-geograficzny województwa płockiego $w$ średniowieczu..., z. 3, s. 249; Kocko-klucz, w: Dzieje Lubelszczyzny, t. 3: Stownik historyczno-geograficzny województwa lubelskiego, oprac. S. Kuraś, Warszawa 1983, s. 105.

${ }^{43}$ J. Topolski, Rozwój latyfundium..., s. 51, 104, 106. 
Dodać należy, że znajdujące się pod Gnieznem Cierpięgi, stanowiące własność gnieźnieńskiej kapituły katedralnej, zostały w 1598 r. nadane przez Karnkowskiego seminarium duchownemu w Gnieźnie. Ponieważ jednak pierwsza fundacja seminarium nie doszła do skutku, dopiero w 1602 r., kolejnym aktem fundacyjnym, arcybiskup zatwierdził uposażenie tej instytucji. Dlatego Cierpięgi do 1600 r. wciąż stanowiły własność kapituły gnieźnieńskiej ${ }^{44}$.

Po przefiltrowaniu danych z przedstawionej przez Henryka Samsonowicza klasyfikacji miast w Polsce około roku $1500^{45}$, zaprezentowanych w tabeli 3, widać, że w przeważającej większości własność kościelna stanowiły miasta małe (III kategoria) lub bardzo małe (IV kategoria) ${ }^{46}$. Według wyliczeń Marii Boguckiej pod koniec XVI stulecia kategorie III i IV stanowiły 88\% miast w Koronie (wraz z Rusią Czerwoną i Warmia), gdzie klasyfikacji dokonano na podstawie szacunkowego ustalenia liczby mieszkańców. Miasta III kategorii (od 600 do 2000 mieszkańców) stanowiły 44,1\% miejscowości, miasta kategorii IV zaś (mniej niż 600 mieszkańców) - 43,9\% ${ }^{47}$.

Do największych i najważniejszych miast kościelnych zaliczyć można te, które w 1520 r. zostały określone jako civitates et oppida secundi ordinis. Były to: Stary Sącz, Skarbimierz, Miechów, Iłża, Bodzentyn, Łowicz, Wolbórz, Uniejów, Żnin, Buk, Słupca, Piątek ${ }^{48}$. Tych 12 miejscowości, należących do 7 podmiotów kościelnych, zostało wymienionych obok takich miast jak Sandomierz, Płock czy Kalisz, stanowiących ośrodki administracji państwowej na szczeblu wojewódzkim. Ponieważ wschodnia część Mazowsza (późniejsze woj. mazowieckie) została inkorporowana do Korony w 1526 r., można założyć, że do miasta tej kategorii włączony zostałby również Pułtusk biskupów płockich. Dałoby to łącznie 13 miast kościelnych w drugiej (z czterech) kategorii podatkowej. Zauważyć trzeba, że $9 \mathrm{z}$ nich (75\%) to miasta biskupie, które proces lokacji przechodziły w okresie od drugiej połowy XIII do pierwszej połowy XIV stulecia.

${ }^{44}$ M. Aleksandrowicz, Poczattkowe dzieje seminarium duchownego $w$ Gnieźnie (1602-1718), „Nasza Przeszłość” 24, 1966, s. 169.

${ }^{45}$ M. Bogucka, H. Samsonowicz, dz. cyt., s. 114-118.

${ }^{46}$ Zob. Z. Kulejewska-Topolska, Oznaczenia $i$ klasyfikacje miast $w$ dawnej Polsce (XVI-XVIII w.), CPH, t. 8, 1956, z. 3, s. 262-263; A. Wyrobisz, Mate miasta $w$ Polsce $w$ XVI $i$ XVII w., w: Miasta doby feudalnej w Europie Środkowo-Wschodniej. Przemiany społeczne a uktady przestrzenne, red. A. Gieysztor, T Rosłanowski, Warszawa 1976, s. 177-187; A.L. Jastrebickaja, Mate miasta. Specyfika średniowiecznej urbanizacji $w$ Europie, KHKM, t. 43, 1995, nr 1, s. 33-42; A. Bartoszewicz, Miasto czy wieś? Małe miasta polskie w późnym średniowieczu, PH, t. 99, 2008, z. 1, s. 122-136.

${ }^{47}$ M. Bogucka, H. Samsonowicz, dz. cyt., s. 371.

${ }^{48}$ Corpus iuris Polonici, seria 1, t. 3, wyd. O. Balzer, Cracoviae 1906, s. 598. 
Tabela 3. Podział miast kościelnych według kategorii podatkowych

\begin{tabular}{|c|c|c|c|c|c|}
\hline \multirow{2}{*}{ Województwo } & \multicolumn{4}{|c|}{ Kategorie podatkowe miast (początek XVI w.) } & \multirow[b]{2}{*}{ brak } \\
\hline & $\mathbf{I}$ & II & III & IV & \\
\hline krakowskie & 0 & 1 & 4 & 4 & 0 \\
\hline siewierskie & 0 & 0 & 1 & 2 & 0 \\
\hline sandomierskie & 0 & 2 & 12 & 7 & 4 \\
\hline lubelskie & 0 & 0 & 0 & 0 & 2 \\
\hline łęczyckie & 0 & 1 & 0 & 2 & 1 \\
\hline sieradzkie & 0 & 2 & 3 & 2 & 1 \\
\hline rawskie & 0 & 1 & 1 & 3 & 0 \\
\hline płockie & 0 & 0 & 1 & 0 & 0 \\
\hline mazowieckie & 0 & 1 & 2 & 6 & 2 \\
\hline poznańskie & 0 & 1 & 6 & 6 & 0 \\
\hline kaliskie & 0 & 2 & 2 & 9 & 2 \\
\hline inowrocławskie & 0 & 0 & 2 & 0 & 0 \\
\hline brzeskie kujawskie & 0 & 0 & 2 & 1 & 0 \\
\hline ziemia dobrzyńska & 0 & 0 & 0 & 1 & 0 \\
\hline chełmińskie & 0 & 0 & 3 & 1 & 0 \\
\hline pomorskie & 0 & 0 & 0 & 0 & 0 \\
\hline malborskie & 0 & 0 & 0 & 0 & 0 \\
\hline podlaskie & 0 & 0 & 0 & 0 & 0 \\
\hline Razem & 0 & 11 & 39 & 44 & 12 \\
\hline
\end{tabular}

Źródło: M. Bogucka, H. Samsonowicz, Dzieje miast i mieszczaństwa w Polsce przedrozbiorowej, Wrocław 1986, s. 114-118.

Miasta II kategorii stanowiły około 10\% wszystkich miast kościelnych. Do wymienionych przez Samsonowicza 11 miast z tej grupy pod koniec XVI w. można by dodać szybko rozwijający się Brok ${ }^{49}$, co daje łącznie 12 osad secundi ordinis, stanowiacych łącznie 11\% interesujących nas miast. Ośrodki III kategorii (39 wyszczególnionych przez badacza) stanowiły blisko 37\%, te najmniejsze zaś (w liczbie 44) $41 \%$. Dwunastu miast, stanowiących $11 \%$ całości, historyk z różnych

${ }^{49}$ M. Bogucka, H. Samsonowicz, dz. cyt., s. 371; I. Gieysztorowa, Charakter i wielkość osad, w: Mazowsze w drugiej połowie XVI wieku..., s. 83; T. Krajewski, dz. cyt., s. 29-40; B. Dymek, Z historii Puszczy Biatej i Broku, „Rocznik Mazowiecki” 17, 2005, s. 108-109. Chociaż H. Samsonowicz, przedstawiając kategorie miast dla Mazowsza, Brok wraz z Andrzejowem i Wyszkowem zaliczył do miast IV, najniższej kategorii; tenże, Gospodarka i społeczeństwo (XIII - poczatek XVI w.), w: Dzieje Mazowsza, t. 1, red. H. Samsonowicz, Pułtusk 2006, s. 393. 
powodów nie uwzględnił. Wydaje się, że poza niewymienionym Miechowem (który w 1520 r. wliczony został do miast secundi ordinis) pozostałe miejscowości oscylowałyby gdzieś między III a IV kategoria.

Im większe i ważniejsze było miasto, tym więcej funkcji mogło pełnić. Najczęściej stanowiło stolicę archidiakonatu (Łowicz, Uniejów bądź Pszczew), ale czasem także główną siedzibę powiatu sądowego (Tarczyn czy Raciąż). Dodać do tego należy funkcje rezydencjonalne i reprezentacyjne ${ }^{50}$. Niektóre $\mathrm{z}$ nich mogły odgrywać rolę kulturalna lub edukacyjna ${ }^{51}$.

Po przyjrzeniu się zamieszczonym mapom sieci miast kościelnych na tle struktury własności ziemskiej polskiego Kościoła widać, że przeważająca większość miast znajdowała się w rejonach, w których zlokalizowane były majątki poszczególnych instytucji. Także nowe próby lokacyjne podejmowano w obrębie istniejących już dóbr. Ich głównym celem było zwiększenie rentowności majątków ${ }^{52}$. Nowe lokacje powiązane były z dalszą akcją lokacyjną i karczunkowa, najprawdopodobniej tylko w przypadku biskupów płockich na wschodnim Mazowszu w Puszczy Białej ${ }^{53}$. Także działania kapituły krakowskiej, czyli ponowienie lokacji Rzgowa i nieudana próba założenia miasta w Brusie, miały zwiazek z procesem intensywniejszej kolonizacji dóbr pabianickich, która nasiliła się dopiero pod koniec XV w. i trwała w następnym stuleciu ${ }^{54}$.

${ }^{50}$ Aspekt ten podejmowany jest przede wszystkim przez badaczy zajmujących się wielką włością możnowładczą w późnośredniowiecznej i wczesnonowożytnej Polsce; zob.: J. Kurtyka, Posiadłość, dziedziczność i prestiż. Badania nad późnośredniowieczna $i$ wczesno nowożytna wielkq wtasnościa możnowtadcza w Polsce XIV-XVII wieku, „Roczniki Historyczne” 65, 1999, s. 187-191; J. Wroniszewski, Szlachta ziemi sandomierskiej $w$ średniowieczu. Zagadnienia społeczne $i$ gospodarcze, Poznań-Wrocław 2001, s. 17-25.

${ }^{51}$ A. Wyrobisz, Rola miast..., s. 43-44. Warto zaznaczyć znaczenie szkół kolegiackich (Z. Skiełczyński, Życie umysłowe $w$ dawnym Łowiczu, „Roczniki Łowickie” 1, 2003, s. 11-13, 24-32) czy pierwsze w XVI w. inicjatywy sprowadzania jezuitów do miast. Jednym z pierwszych miast w Koronie, w którym powstało kolegium jezuickie, był Pułtusk biskupów płockich; J. Szczepański, Kolegium jezuickie w Pułtusku 1566-1772, w: Dzieje Gimnazjum i Liceum im. Piotra Skargi w Puttusku, red. D. Ciok, A. Kociszewski, J. Szczepański, Ciechanów-Pułtusk 1992, s. 32.

${ }^{52}$ A. Wyrobisz, Rola miast..., s. 24.

${ }^{53}$ T. Krajewski, dz. cyt., s. 29-40; H. Samsonowicz, Ośrodki gospodarcze w Puszczy Białej na poczatku XIX wieku, „Zeszyty Naukowe Ostrołęckiego Towarzystwa Naukowego" 6,1992 , s. 46-48.

${ }^{54}$ Wynikało to zapewne z niepowodzenia, jakim była próba zamiany klucza pabianickiego na położony na terenie woj. sandomierskiego klucz piórkowski biskupa włocławskiego; M. Baruch, Pabianice, Rzgów i wsie okoliczne. Monografia historyczna dawnych dóbr kapituty krakowskiej $w$ sieradzkiem $i$ tęczyckiem, Warszawa 1903, s. 36-38; M.D. Kowalski, dz. cyt., s. 55-59. 
Niezależnie od wielkości miasta, każde z nich pełniło funkcje handlowo-gospodarcze, nawet jeśli przeważająca większość mieszkańców trudniła się rolnictwem ${ }^{55}$. Miasto mogło obsługiwać jedynie najbliższe otoczenie (tak najczęściej było z ośrodkami małymi i bardzo małymi), ale też stanowić spore centrum wymiany towarowo-pieniężnej (cotygodniowe targi, jarmarki) ${ }^{56}$.

Miasto stanowiło centrum gospodarcze klucza. Istniały przy nich duże skupiska urządzeń gospodarczych, przede wszystkim młynów wodnych, ale też - w zależności od warunków środowiskowych - wiatraków ${ }^{57}$, kuźnic ${ }^{58}$ czy młynów kieratowych ${ }^{59}$. Koło Wolborza pod koniec XVI w. funkcjonowało sześć młynów wodnych, w tym jeden zamkowy, podobnie wiele młynów wymienia inwentarz z 1598 r. koło Łodzi - było ich w tym okresie pięćc ${ }^{60}$.

Cechą wspólną dla większości miast, tak małych, jak i dużych, był fakt przebywania $\mathrm{w}$ nich osób odpowiedzialnych za administrowanie

${ }^{55}$ H. Samsonowicz, Wiejskość osad miejskich w późnym średniowieczu, w: Civitas \& villa. Miasto $i$ wieś $w$ średniowiecznej Europie środkowej, [red. C. Buśko i in.], Wrocław-Praha 2002, s. 13-16.

${ }^{56}$ A. Wyrobisz, Mate miasta..., s. 183-184.

${ }^{57} \mathrm{~W}$ rejestrach poborowych woj. poznańskiego z drugiej połowy XVI w. w Krobi odnotowano opłaty od 3 do 11 wiatraków dorocznych i dziedzicznych. Z ośmiu poborów od wiatraków najczęściej - czterokrotnie - płacono od 10 wiatraków. Wykorzystano dane dostępne w witrynie Atlasfontium.pl: Atlas historyczny Polski. Rejestry poborowe województwa poznańskiego w XVI wieku, red. M. Słoń, „Atlas Źródeł i Materiałów do Dziejów Dawnej Polski” 3, 2015.

${ }^{58}$ Liczne kuźnice występowały wokół miast znajdujących się w woj. sandomierskim, głównie w silnie wykorzystywanym w tym celu rejonie Gór Świętokrzyskich, np. w okolicach Bodzentyna, Łagowa i innych miejscowości; Inwentarz dóbr i dochodów biskupstwa włoctawskiego z roku 1534, wyd. B. Ulanowski, „Archiwum Komisji Historycznej” 10, 1916, s. 107-109; L. Stępkowski, Bodzentyn nowożytny. Z dziejów miasta biskupiego w XVI-XVIII wieku, w: Bodzentyn. Z dziejów miasta w XII-XX wieku, red. K. Bracha, Kielce 1998, s. 82-83; R. Kubicki, W. Saletra, Hutnictwo i górnictwo w regionie świętokrzyskim - do Księstwa Warszawskiego, „Studia i Materiały Wydziału Zarządzania i Administracji Wyższej Szkoły Pedagogicznej im. Jana Kochanowskiego w Kielcach. Miscellanea Oeconomicae" 17, 2013, nr 2, s. 30-33.

${ }^{59} \mathrm{~W}$ wielkopolskich dobrach biskupów poznańskich młyny kieratowe w $1564 \mathrm{r}$. znajdowały się w Buku, Krobi, Dolsku i Słupcy; Inwentarz dóbr i dochodów biskupów poznańskich z roku 1564, wyd. E. Długopolski, „Archiwum Komisji Historycznej” 15, 1939, s. 294-300.

${ }^{60}$ Revisio bonorum episcopatus Wladislaviensis facta Anno 1598, wyd. L. Żytkowicz, Torunii 1950, s. 167; R. Rosin, Wolbórz i jego okolice w XI-XVI w. Kasztelania - osadnictwo - miasto, w: 400-lecie śmierci Andrzeja Frycza Modrzewskiego. 700-lecie nadania praw miejskich Wolborzowi. Materiaty sesji popularnonaukowej z 24 IX 1972 r., red. R. Rosin, Łódź 1975, s. 52; S.M. Zajaczkowski, Uwagi nad dziejami dóbr łaznowskich $i$ niesutkowskich biskupstwa włocławskiego do końca XVI wieku, Łódź 2000, s. 92-97. 
majątkiem. Zazwyczaj bowiem wokół miasta skupiony był klucz dóbr złożony z kilku do kilkunastu wsi ${ }^{61}$. Najczęściej też miasto lokowane w XVI w. stanowiło wcześniej centrum administracyjne klucza. To do niego poddani danej instytucji zwozili opłaty w pieniądzu bądź naturze, często również w znajdujących się w nich folwarkach czy dworach wypełniali różnego rodzaju posługi. Do tych centrów ściagano również świadczenia z racji dziesięciny. Można mniemać, że tak miało być w przypadku chociażby Kochowa, należącego do klasztoru z Czerwińska, który miał stanowić główne centrum oddalonego od siedziby klasztoru klucza. Miało to chyba jeszcze bardziej usprawnić zarząd najdalej na południe wysuniętej części uposażenia czerwińskich kanoników.

Kwestie administracyjne były zapewne główna przyczyną zakupienia przez kapitułę gnieźnieńską części miasteczka Toporów. Było ono położone w bezpośredniej bliskości klucza wieluńskiego, od $1555 \mathrm{r}$. stanowiącego własność kapituły gnieźnieńskiej ${ }^{62}$. Aby sprawnie zarządzać nabytkiem, potrzebne było centrum, w którym można było zarówno ulokować system administracji majątkiem, jak i stworzyć miejsce wymiany towarowo-pieniężnej.

Zdarzało się, że w największych skupiskach majątkowych powstawały kolejne miasta. Tak było np. w przypadku Daleszyc, położonych w kluczu kieleckim biskupstwa krakowskiego. Już w XVII w. wydzielony został osobny klucz z centrum w tym mieście ${ }^{63}$. Co ciekawe, wspomniana arcybiskupia próba przekształcenia Chełmna nad Nerem w miasto korelowała z wyodrębnieniem się z części klucza uniejowskiego i grzegorzewskiego osobnego klucza chełmińskiego. Być może planowana lokacja Chełmna związana była zarówno z usprawnieniem zarządzania tym niewielkim kluczem, jak i potrzebą wzrostu możliwości upieniężnienia dochodów z okolicznych osad (być może nie tylko arcybiskupich). Taki sam zamysł stał zapewne za próba lokacji miasta pod zamkiem biskupów krakowskich w Lipowcu, w połowie XVI w.

${ }^{61}$ Zob. przykład cysterskiego Jędrzejowa, który stanowił centrum dla wsi tamtejszego opactwa cysterskiego. Wsie te znajdowały się w promieniu 10-15 km od Jędrzejowa; H. Gapski, Cystersi jędrzejowscy w czasach nowożytnych (XVI-XVIII wiek), w: Cystersi w Polsce. W 850-lecie fundacji opactwa jędrzejowskiego, red. D. Olszewski, Kielce 1990, s. 91. Na funkcję małych miast jako centrów kluczy majątkowych zwracał uwagę A. Wyrobisz; zob. tenże, Rola miast..., s. 27-28, na s. 26 przykładowe mapki dóbr możnowładczych.

62 J. Topolski, Rozwój latyfundium..., s. 105.

63 J. Muszyńska, Biskupi krakowscy rzadcami dóbr sandomierskich (od połowy XV do połowy XVII wieku), w: Kościót krakowski w życiu państwa i narodu polskiego, red. A. Pankowicz, Kraków 2002, s. 103. 
Czasem jednak, kiedy wydzielano $\mathrm{z}$ obszernych kluczy majątkowych mniejsze jednostki zarządu gospodarczego, zwane podkluczami, ich centrami ustanawiano miejscowości, w których znajdował się folwark. Taki podział można zaobserwować w biskupich kompleksach dóbr łowickich czy wolborskich ${ }^{64}$. Na podstawie dostępnych wzmianek można stwierdzić, że podobnie zorganizowane były dobra klasztorne, zwłaszcza te ich skupiska, które pozostawały w znacznym oddaleniu od siedziby konwentu ${ }^{65}$.

Nie każde miasto stanowiło centrum klucza, przynajmniej nominalnie. Wydaje się, że niekiedy centrum zarządu administracyjnego pozostawało we wsi, w której znajdował się folwark, dwór bądź siedziba klasztoru. Za przykład może posłużyć sytuacja w dobrach niesułkowskich biskupów włocławskich. We wsi Niesułków znajdował się dwór biskupi, a zarządcy dóbr nazywani byli najczęściej starostami bądź tenutariuszami niesułkowskimi. Wchodząca w skład tego klucza Łódź miała pełnić funkcje ośrodka handlowo-gospodarczego ze względu na korzystniejsze położenie niż Niesułków ${ }^{66}$. Podobna sytuacja miała miejsce w dobrach biskupów poznańskich. Rezydencja poznańskich ordynariuszy znajdowała się w Ciążeniu, jednak to w Słupcy funkcjonowało miasto, jedno z najprężniejszych w całym woj. kaliskim ${ }^{67}$. Trudno na tym etapie badań odpowiedzieć na pytanie, czy nazywanie dóbr i ich zarządców niesułkowskimi bądź ciążeńskimi wynikało wyłącznie z siły tradycji, choć fakt ugruntowania pozycji Niesułkowa i Ciążenia jako miejsc rezydencjonalnych biskupów miał zapewne na to wpływ.

W dobrach kościelnych znaleźć można również klucze, w których w XVI w. miast nie było. Takie sytuacje nie zdarzały się często.

${ }^{64}$ Wizytacje dóbr arcybiskupstwa gnieźnieńskiego i kapituty gnieźnieńskiej z XVI wieku, wyd. B. Ulanowski, Kraków 1920, s. 22-133; Inwentarz dóbr stołowych biskupstwa włocławskiego z roku 1582, wyd. L. Żytkowicz, Toruń 1953, s. 82-182; Revisio bonorum episcopatus Wladislaviensis facta Anno 1598..., s. 92-155. Analogicznie w dobrach biskupów krakowskich zob. Z. Górczak, Dobra stołowe biskupstwa krakowskiego za pontyfikatu Zbigniewa Oleśnickiego (1423-1455), w: Zbigniew Oleśnicki, ksiażę Kościoła i maż stanu. Materiaty z konferencji Sandomierz 20-21 maja 2005 roku, red. F. Kiryk, Z. Noga, Kraków 2006, s. 245.

${ }_{65}$ M. Zdanek, Dochodowość majatku klasztoru cystersów w Mogile w połowie XVI w. na podstawie inwentarza dóbr z lat 1560-1566, w: Klasztor $w$ gospodarce średniowiecznej i nowożytnej, red. M. Derwich, Wrocław 2013, s. 258; por. z ogólniejszymi konstatacjami: K. Mikulski, J. Wroniszewski, Folwark i zmiany koniunktury gospodarczej $w$ Polsce XIV-XVII wieku, „Klio. Czasopismo poświęcone dziejom Polski i powszechnym" 4, 2003, s. 29.

${ }^{66}$ S. Inglot, Stosunki społeczno-gospodarcze ludności $w$ dobrach biskupstwa włocławskiego w pierwszej połowie XVI wieku, Lwów 1927, s. 10-11.

${ }^{67}$ Inwentarz dóbr i dochodów biskupów poznańskich z roku 1564..., s. 294-300. 
Inwentarz dóbr biskupstwa poznańskiego z 1564 r. nie wymienia żadnego miasta $\mathrm{w}$ kluczu soleckim ${ }^{68}$. Być może wynikało to $\mathrm{z}$ rozproszenia osadniczego tego klucza oraz względnego zagęszczenia sieci miejskiej w rejonie granicy między powiatami pyzdrskim a kościańskim. Miasta nie było też w kluczu lubotyńskim biskupów włocławskich. Był to mały klucz, w inwentarzach z 1534 i 1582 r. wymieniono w nim 5-6 wsi, podzielony na dwie części, północną i południowa, przedzielony osadnictwem innych kategorii własności ${ }^{69}$. Można zatem przypuszczać, że powody braku lokacji miasta do końca XVI w. mogły być podobne jak w przypadku klucza soleckiego.

Liczebność osad w kluczu, w którym miało powstać lub powstawało miasto, była różna. Nie ma ściśle określonego modelu, w którym można by zaprezentować minimalną liczbę miejscowości potrzebną do założenia miasta. Koło Jeżowa benedyktynów lubińskich funkcjonował klucz złożony z 4 wsi. W bezpośredniej bliskości cysterskiego Wagrowca, $\mathrm{w}$ promieniu $10 \mathrm{~km}$ od miasta, znajdowało się 21 osad należących do tamtejszego klasztoru. Wokół lokowanego w XVI w. Stoczka istniało już 12 miejscowości. Na pewno była to liczba wystarczająca do funkcjonowania miasta, nawet mimo niewielkiej odległości Stoczka od innych ośrodków miejskich.

Na ziemiach polskich można znaleźć kilka przypadków miast, które znajdowały się niekiedy w dość znacznej odległości od kluczy majattkowych i skupisk własnościowych. Zaliczyć do nich można Święciechowę benedyktynów lubińskich, Kostrzyn klarysek gnieźnieńskich, Ślesin biskupów poznańskich i Łęgonice arcybiskupów gnieźnieńskich. Znaczenie Ślesina dla biskupów poznańskich wiązało się przede wszystkim z istnieniem w tym mieście już od XIII w. komory celnej, funkcjonującej również w XVI w. ${ }^{70}$ Tak samo lokację miasta w Święciechowie należałoby łączyć z posiadanymi tam przez benedyktynów z Lubinia dochodami z cła ${ }^{71}$. Podobnie w przypadku Łęgonic. Jednym z najważniejszych czynników istnienia tam miasta musiała być przeprawa

${ }_{68}$ Tamże, s. 290-294; W. Sobisiak, dz. cyt., s. 43-47.

${ }^{69}$ Inwentarz dóbr $i$ dochodów biskupstwa włocławskiego z roku 1534..., s. 20-23; Inwentarz dóbr stołowych biskupstwa włocławskiego z roku 1582..., s. 29-32.

${ }^{70}$ Inwentarz dóbr i dochodów biskupów poznańskich z roku 1564..., s. 300; M. Brust, Geneza i poczatki miast $w$ dobrach biskupów poznańskich $w$ Wielkopolsce (XIII-XIV wiek), cz. 2, „Nasza Przeszłość” 101, 2004, s. 121-122. Dopiero w pierwszej połowie XVII w. ze wschodniej części klucza ciążeńskiego wyodrębniono klucz młodojewski, w skład którego wchodził Ślesin; W. Sobisiak, dz. cyt., s. 41.

${ }^{71}$ Z. Perzanowski, Opactwo benedyktyńskie w Lubiniu. Studia nad fundacja i rozwojem uposażenia w średniowieczu, Wrocław 1978, s. 99-100. 
przez Pilicę, choć bliskość Nowego Miasta mogłaby sugerować pewne trudności $\mathrm{w}$ tym względzie ${ }^{72}$. Z Łęgonicami w inwentarzach dóbr wiazano grupę wsi arcybiskupich leżących na lewym brzegu Wisły w ziemi czerskiej, traktując je jako osobny klucz majątkowy. Odległość między nimi a Łęgonicami wynosiła około $115 \mathrm{~km}$. Miasto stanowiło jednak centrum klucza dziesięcinnego, w skład którego wchodziło w $1511 \mathrm{r}$. blisko 200 osad $^{73}$.

Tych kilka spostrzeżeń, dalekich od pełnego zanalizowania sieci miast należących do instytucji kościelnych w XVI w., wpisuje się w ogólny schemat rozwoju sieci miejskiej w czasach nowożytnych. Jeśli powstawały nowe miasta, to w większości były one ośrodkami małymi, celem ich lokacji była zaś przede wszystkim lepsza organizacja administracji dobrami stołowymi i majątkiem kościelnym oraz stworzenie miejsca zbytu dla produktów wytwarzanych we wsiach znajdujących się w okolicach nowego założenia miejskiego, głównie dla ludności zamieszkującej osady należące do uposażenia biskupa, klasztoru czy kapituł katedralnych i kolegiackich. Konieczne jest jednak o wiele dokładniejsze przyjrzenie się omawianym wyżej zagadnieniom, co wymaga bardziej szczegółowych badań.

${ }^{72}$ MRPS, cz. 4, t. 1, nr 1473, 5367; zob. też Wizytacje dóbr arcybiskupstwa gnieźnieńskiego..., s. 339-341 (informacje o sporach mieszczan łęgonickich z właścicielami Nowego Miasta nad Pilicą o pobór mostowego).

${ }^{73}$ Wizytacje dóbr arcybiskupstwa gnieźnieńskiego..., s. 336-348 (opis klucza łęgonickiego), 349-352 (rejestr dziesięcin klucza łęgonickiego); J. Topolski, Rozwój latyfundium..., s. 108-112. Analogiczne klucze dziesięcinne funkcjonowały na terenie biskupstwa krakowskiego; zob. Z. Górczak, dz. cyt., s. 246. 


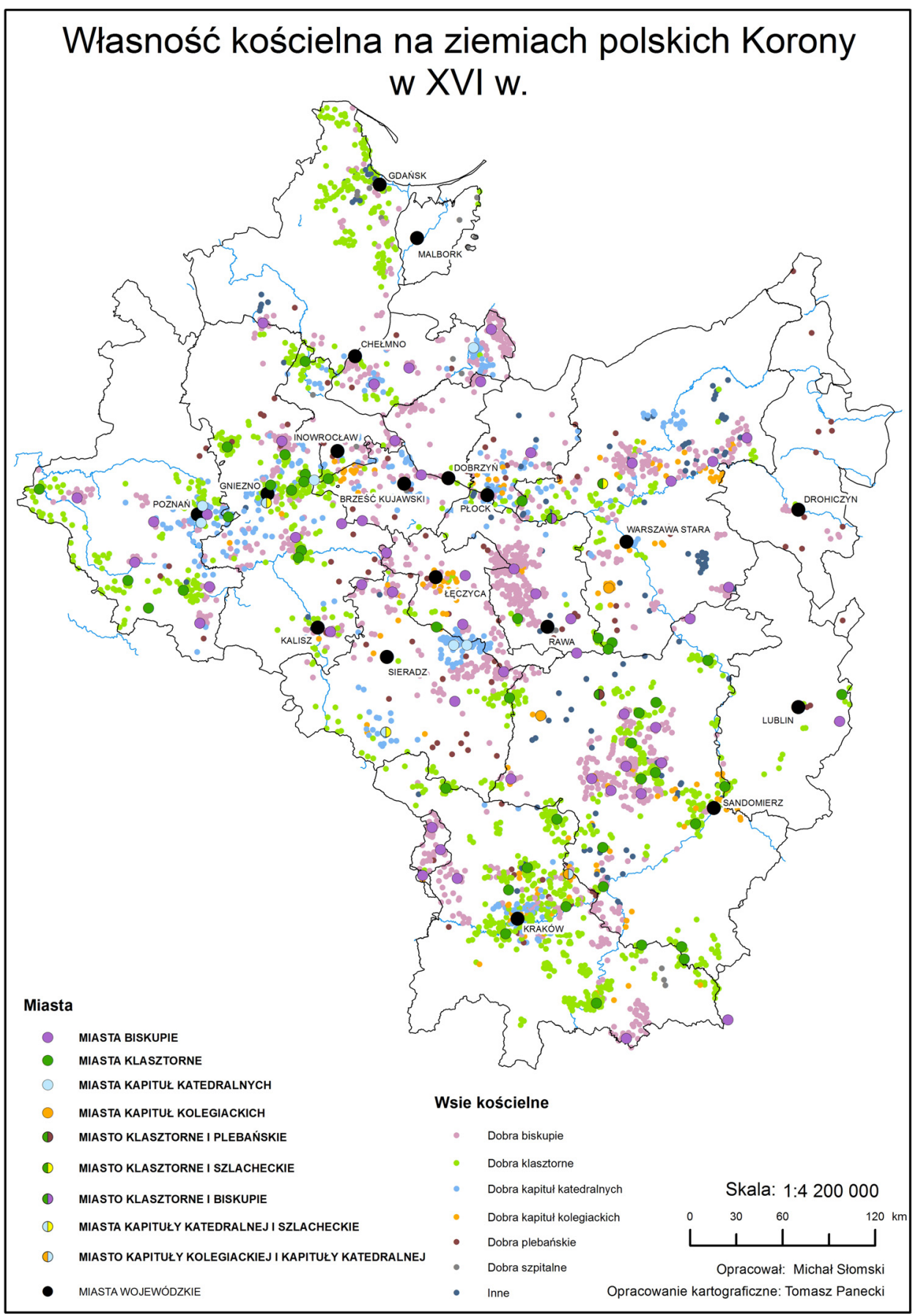




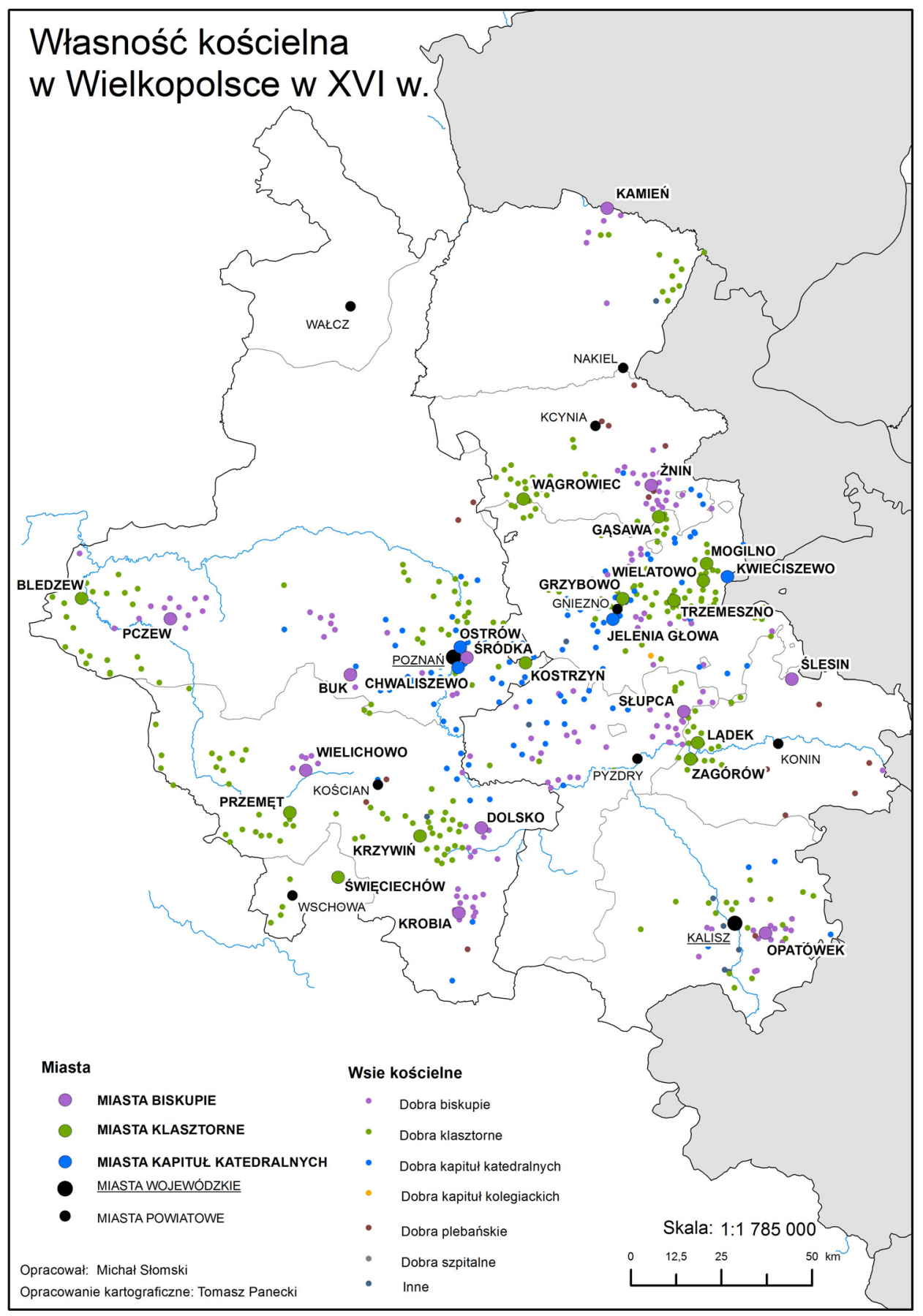


Aneks: Miasta w posiadaniu instytucji kościelnych około 1600 r. (+ zaznaczono miasta powstałe w XVI w.)

Arcybiskup gnieźnieński: Grocholice, Grzegorzewo, Kamień, Kurzelów, Łęgonice, Łowicz, Opatówek, Piątek, Skierniewice, Sompolno, Turek, Uniejów, Żnin. Biskup krakowski: Biskupice, Bodzentyn, Czeladź, Daleszyce (+), Iłża, Jastrząb, Kielce, Koziegłowy, Kunów, Muszyna, Siewierz, Sławków. Biskup poznański: Buk, Dolsk, Krobia, Łaskarzew, Pszczew, Słupca, Stoczek (+), Ślesin, Śródka, Wielichowo. Biskup płocki: Andrzejów (+), Brok (+), część Czerwińska, Górzno, Pułtusk, Raciąż, Wyszków (+). Biskup włocławski: Łagów, Łódź, Raciążek, Włocławek, Wolbórz. Biskup chełmiński: Chełmża, Lubawa, Wąbrzeźno. Biskup chełmski: Biała. Biskup przemyski: Jaśliska.

Benedyktyni lubińscy: Krzywiń, Święciechowa, Jeżów. Benedyktyni mogileńscy: Mogilno. Benedyktyni płoccy: Przybyszewo, Wyśmierzyce. Benedyktyni sieciechowscy: Puchaczów (+), Sieciechów. Benedyktyni świętokrzyscy: Słup Nowa. Benedyktyni tynieccy: Brzostek, Kołaczyce, Opatowiec, Skawina, Tuchów. Bożogrobcy gnieźnieńscy: część Grzybowa. Bożogrobcy miechowscy: Miechów, Skaryszew. Cystersi bledzewscy: Bledzew. Cystersi jędrzejowscy: Jędrzejów. Cystersi koprzywniccy: Koprzywnica. Cystersi koronowscy: Koronowo. Cystersi lądeccy: Lądek, Zagórów. Cystersi przemęccy: Przemęt. Cystersi sulejowscy: Mogilnica, część Skrzynna, Sulejów. Cystersi wąchoccy: Waśniów, Wąchock, Wierzbica. Cystersi wągrowieccy: Wagrowiec. Kanonicy regularni z Czerwińska: część Nasielska, część Czerwińska. Kanonicy regularni z Mstowa: Mstów. Kanonicy regularni z Trzemeszna: Gąsawa, Kazimierz, Trzemeszno, Wylatowo. Klaryski gnieźnieńskie: część Grzybowa, Kostrzyn. Klaryski krakowskie: Skała, Zawichost. Klaryski starosądeckie: Stary Sącz. Norbertanie hebdowscy: Brzesko Nowe. Norbertanki buskie: Busko. Norbertanki płockie: Bodzanów. Norbertanki strzelneńskie: Strzelno.

Kapituła katedralna w Chełmży: Kurzętnik. Kapituła katedralna w Gnieźnie: część Jędrzejewa, Kwieciszewo, część Toporowa. Kapituła katedralna w Krakowie: Pabianice, Rzgów (+), część Skarbimierza (kolegium wikariuszy). Kapituła katedralna w Poznaniu: Chwaliszewo, Ostrów.

Kolegiata sandomierska: Żarnów. Kolegiata skarbimierska (prepozyt): część Skarbimierza. Kolegiata warszawska: Tarczyn.

Pleban skrzynecki: część Skrzynna. 


\section{Bibliografia}

\section{Źródta archiwalne}

AGAD, Archiwum Skarbu Koronnego, dział I, t. 12-13.

\section{Źródta opublikowane}

Atlas historyczny Polski. Rejestry poborowe województwa kaliskiego w XVI wieku, red. M. Słoń, „Atlas Źródeł i Materiałów do Dziejów Dawnej Polski" 2, 2015, Atlasfontium.pl.

Atlas historyczny Polski. Rejestry poborowe województwa poznańskiego w XVI wieku, red. M. Słoń, „Atlas Źródeł i Materiałów do Dziejów Dawnej Polski" 3, 2015, Atlasfontium.pl.

Corpus iuris Polonici, seria 1, t. 3, wyd. O. Balzer, Cracoviae 1906.

Gawarecki W.H., Przywileje, nadania i swobody, przez królów polskich, ksiażat mazowieckich $i$ biskupów płockich udzielone miastom województwa płockiego, Warszawa 1828.

Inwentarz dóbr i dochodów biskupów poznańskich z roku 1564, wyd. E. Długopolski, „Archiwum Komisji Historycznej” 15, 1939, s. 267-348.

Inwentarz dóbr i dochodów biskupstwa włoctawskiego z roku 1534, wyd. B. Ulanowski, „Archiwum Komisji Historycznej” 10, 1916, s. 1-128.

Inwentarz dóbr stotowych biskupstwa włoctawskiego z roku 1582, wyd. L. Żytkowicz, Torun 1953.

MRPS, cz. 4: Sigismundi I regis tempora complectens (1507-1548), t. 1: Acta cancellariorum 1507-1548, wyd. T. Wierzbowski, Varsoviae 1910.

Polska XVI wieku pod względem geograficzno-statystycznym, t. 2: Wielkopolska, oprac. A. Pawiński, Warszawa 1883 (Źródła Dziejowe, 13).

Polska XVI wieku pod względem geograficzno-statystycznym, t. 5: Mazowsze, oprac. A. Pawiński, Warszawa 1895 (Źródła Dziejowe, 16).

Polska XVI wieku pod względem geograficzno-statystycznym, t. 6, cz. 2: Podlasie, oprac. A. Jabłonowski, Warszawa 1909 (Źródła Dziejowe, 17/2).

Revisio bonorum episcopatus Wladislaviensis facta Anno 1598, wyd. L. Żytkowicz, Torunii 1950.

Wizytacje dóbr arcybiskupstwa gnieźnieńskiego i kapituty gnieźnieńskiej $z$ XVI wieku, wyd. B. Ulanowski, Kraków 1920.

\section{Opracowania}

Aleksandrowicz M., Poczatkowe dzieje seminarium duchownego w Gnieźnie (1602-1718), „Nasza Przeszłość” 24, 1966, s. 167-185.

Bartoszewicz A., Miasto czy wieś? Mate miasta polskie w późnym średniowie$c z u, \mathrm{PH}$, t. 99, 2008, z. 1, s. 122-136. 
Baruch M., Pabianice, Rzgów i wsie okoliczne. Monografia historyczna dawnych dóbr kapituty krakowskiej $w$ sieradzkiem i tęczyckiem, Warszawa 1903.

Biskup M., Rozmieszczenie wtasności ziemskiej województwa chetmińskiego i malborskiego $w$ drugiej połowie XVI w. (mapa i materiaty), Torun 1957.

Biskup M., Rozwój sieci miast pruskich do drugiej połowy XVII w., KHKM, t. 28,1980, nr 3, s. 401-412.

Biskup M., Średniowieczna sieć klasztorów w państwie zakonu krzyżackiego, „Zapiski Historyczne” 64, 1999, z. 1, s. 35-61.

Biskup M., Tomczak A., Mapy województwa pomorskiego w drugiej połowie XVI w. I. Rozmieszczenie własności ziemskiej, II. Sieć parafialna, Toruń 1955.

Bogucka M., Samsonowicz H., Dzieje miast i mieszczaństwa w Polsce przedrozbiorowej, Wrocław 1986.

Brust M., Geneza i poczatki miast $w$ dobrach biskupów poznańskich $w$ Wielkopolsce (XIII-XIV wiek), cz. 2, „Nasza Przeszłość” 101, 2004, s. 79-147.

Chłapowski K., Przynależność wtasnościowa osiedli i Aneks II. Dobra w posiadaniu instytucji kościelnych w końcu XVI w., w: Województwo krakowskie $w$ drugiej połowie XVI wieku, red. H. Rutkowski, cz. 2: Komentarz. Indeksy, Warszawa 2008 (Atlas Historyczny Polski. Mapy Szczegółowe XVI wieku, 1), s. 83-93, 100-106.

Chłapowski K., Dunin-Wassowiczowa A., Przynależność własnościowa osiedli i Aneks II: Dobra w posiadaniu instytucji kościelnych w końcu XVI wieku, w: Województwo sieradzkie i województwo tęczyckiej w drugiej połowie XVI wieku, red. S. Trawkowski, cz. 2: Komentarze. Indeksy, Warszawa 1998 (Atlas Historyczny Polski. Mapy Szczegółowe XVI wieku, 5), s. 58-64, $67-70$.

Derwich M., Klasztor a miasto $w$ średniowieczu $w$ historiografii europejskiej. Próba podsumowania, w: Klasztor $w$ mieście średniowiecznym $i$ nowożytnym. Materiaty $z$ międzynarodowej konferencji naukowej zorganizowanej $w$ Turawie $w$ dniach 6-8 V 1999 r. przez Instytut Historii Uniwersytetu Opolskiego i Instytut Historyczny Uniwersytetu Wroctawskiego, red. M. Derwich, A. Pobóg-Lenartowicz, Wrocław-Opole 2000, s. 21-50.

Dunin-Wąsowicz A., Większe kompleksy dóbr w posiadaniu instytucji kościelnych $w$ woj. sandomierskim w ostatniej ćwierci XVI w., w: Województwo sandomierskie $w$ drugiej połowie XVI wieku, red. W. Pałucki, cz. 2: Komentarz. Indeksy, Warszawa 1993 (Atlas Historyczny Polski. Mapy Szczególowe XVI wieku, 2), s. 112-113.

Dymek B., Z historii Puszczy Biatej i Broku, „Rocznik Mazowiecki” 17, 2005, s. $105-111$.

Dzieje Lubelszczyzny, t. 3: Stownik historyczno-geograficzny województwa lubelskiego, oprac. S. Kuraś, Warszawa 1983.

Gapski H., Cystersi jędrzejowscy w czasach nowożytnych (XVI-XVIII wiek), w: Cystersi w Polsce. W 850-lecie fundacji opactwa jędrzejowskiego, red. D. Olszewski, Kielce 1990, s. 80-96. 
Gieysztorowa I., Charakter i wielkość osad, w: Mazowsze $w$ drugiej połowie XVI wieku, red. W. Pałucki, cz. 2: Komentarz. Indeksy, Warszawa 1973 (Atlas Historyczny Polski. Mapy Szczegółowe XVI wieku, 7), s. 77-87.

Górczak Z., Dobra stołowe biskupstwa krakowskiego za pontyfikatu Zbigniewa

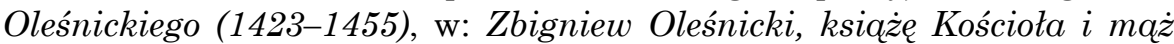
stanu. Materiaty z konferencji Sandomierz 20-21 maja 2005 roku, red. F. Kiryk, Z. Noga, Kraków 2006, s. 241-270.

Górska-Gołaska K., Kazimierz Biskupi w średniowieczu, w: Dzieje Kazimierza Biskupiego, cz. 1: Monografia, red. Z. Chodyła, Kazimierz Biskupi-Konin 2001, s. 11-72.

Grzegorz M., Lokacja miast na Pomorzu Gdańskim w latach 1309-1454 na tle działalności politycznej i gospodarczej oraz administracyjnej zakonu krzyżackiego, w: W kręgu stanowych i kulturowych przeobrażen Europy Pótnocnej $w$ XIV-XVIII wieku, red. Z.H. Nowak, Torun 1988, s. 39-55.

Grzegorz M., Struktura administracyjna i własnościowa Pomorza Gdańskiego pod rzadami zakonu krzyżackiego $w$ latach 1309-1454, Warszawa-Poznań-Torun 1987.

Guldon Z., Mapy ziemi dobrzyńskiej w drugiej połowie XVI w. I. Podziaty administracyjne, II. Rozmieszczenie własności ziemskiej, Torun 1967.

Guldon Z., Rozmieszczenie własności ziemskiej na Kujawach w II połowie XVI w., Toruń 1964.

Inglot S., Stosunki społeczno-gospodarcze ludności w dobrach biskupstwa wtocławskiego w pierwszej połowie XVI wieku, Lwów 1927.

Jastrebickaja Ałła J., Małe miasta. Specyfika średniowiecznej urbanizacji $w$ Europie, KHKM, t. 43, 1995, nr 1, s. 33-42.

Karczewski D., Rozwój sieci miast klasztornych w Polsce do połowy XVI wieku, w: Klasztor $w$ mieście średniowiecznym $i$ nowożytnym. Materiały $z$ międzynarodowej konferencji naukowej zorganizowanej $w$ Turawie $w$ dniach 6-8 V 1999 r. przez Instytut Historii Uniwersytetu Opolskiego i Instytut Historyczny Uniwersytetu Wrocławskiego, red. M. Derwich, A. Pobóg-Lenartowicz, Wrocław-Opole 2000, s. 137-150.

Kiryk F., Lokacje miast biskupich w prepozyturze kieleckiej, w: Pamiętnik świętokrzyski. Studia z dziejów kultury chrześcijańskiej. Praca zbiorowa, Kielce 1991, s. 47-63.

Kiryk F., Lokacje miejskie nieudane, translacje miast i miasta zanikte $w$ Małopolsce do połowy XVII stulecia, KHKM, t. 28, 1980, nr 3, s. 373-384.

Kiryk F., Skrzynno Opackie i Skrzynno Plebańskie - miasta bliźniacze i konkurencyjne (XIII-XVIII wiek), w: Narodziny Rzeczypospolitej. Studia z dziejów średniowiecza i czasów wczesno nowożytnych, t. 1, red. W. Bukowski, T. Jurek, Kraków 2012, s. 595-627.

Kowalski M.D., Uposażenie krakowskiej kapituty katedralnej $w$ średniowie$c z u$, Kraków 2000.

Krajewski T., Społeczno-gospodarczy rozwój i upadek Broku w XVI-XVII wieku, w: Brok i Puszcza Biała. Przeszłość - środowisko geograficzne, kulturowe i przyrodnicze, Ciechanów 1989, s. 28-41. 
Kubicki R., Saletra W., Hutnictwo i górnictwo $w$ regionie świętokrzyskim do Księstwa Warszawskiego, „Studia i Materiały Wydziału Zarządzania i Administracji Wyższej Szkoły Pedagogicznej im. Jana Kochanowskiego w Kielcach. Miscellanea Oeconomicae” 17, 2013, nr 2, s. 29-40.

Kulejewska-Topolska Z., Nowe lokacje miejskie $w$ Wielkopolsce od XVI do końca XVIII wieku. Studium historyczno-prawne, Poznań 1964.

Kulejewska-Topolska Z., Oznaczenia $i$ klasyfikacje miast $w$ dawnej Polsce (XVI-XVIII w.), CPH, t. 8, 1956, z. 3, s. 253-268.

Kurtyka J., Posiadłość, dziedziczność i prestiż. Badania nad późnośredniowieczna $i$ wczesno nowożytna wielka wtasnościa możnowtadcza $w$ Polsce XIV-XVII wieku, „Roczniki Historyczne” 65, 1999, s. 161-194.

Lalik T., Regale targowe ksiażat wschodniopomorskich $w$ XII-XIII w., PH, t. 56, 1965, s. 171-201.

Laszuk A., Zaścianki i królewszczyzny. Struktura własności ziemskiej w województwie podlaskim w drugiej połowie XVII wieku, Warszawa 1998.

Malinowska J., Studia osadnicze na obszarze powiatu brzezińskiego do połowy XVI wieku, Toruń 2002.

Mikulski K., Wroniszewski J., Folwark $i$ zmiany koniunktury gospodarczej $w$ Polsce XIV-XVII wieku, „Klio. Czasopismo poświęcone dziejom Polski i powszechnym" 4, 2003, s. 25-39.

Muszyńska J., Biskupi krakowscy rzqdcami dóbr sandomierskich (od połowy XV do połowy XVII wieku), w: Kościót krakowski w życiu państwa i narodu polskiego, red. A. Pankowicz, Kraków 2002, s. 95-112.

Nowacki J., Dzieje archidiecezji poznańskiej, t. 2: Archidiecezja poznańska $w$ granicach historycznych $i$ jej ustrój, Poznań 1964.

Pałucki W., Przynależność wtasnościowa osad, w: Mazowsze $w$ drugiej połowie XVI wieku, red. W. Pałucki, cz. 2: Komentarz. Indeksy, Warszawa 1973 (Atlas Historyczny Polski. Mapy Szczegółowe XVI wieku, 7), s. 88-102.

Pałucki W., Przynależność własnościowa osad, w: Województwo sandomierskie $w$ drugiej połowie XVI wieku, red. W. Pałucki, cz. 2: Komentarz. Indeksy, Warszawa 1993 (Atlas Historyczny Polski. Mapy Szczegółowe XVI wieku, 2), s. 87-98.

Pazyra S., Studia z dziejów miast na Mazowszu od XIII do poczatków XX wieku, Lwów 1939.

Perzanowski Z., Opactwo benedyktyńskie w Lubiniu. Studia nad fundacja $i$ rozwojem uposażenia $w$ średniowieczu, Wrocław 1978.

Piotrkowska U., Struktura i rozmieszczenie własności ziemskiej $w$ powiatach poznańskim i wałeckim $w$ drugiej połowie XVI wieku, „Studia i Materiały do Dziejów Wielkopolski i Pomorza" 17, 1989, z. 1, s. 5-112.

Piotrkowska U., Struktura $i$ rozmieszczenie własności ziemskiej $w$ powiecie kościańskim i ziemi wschowskiej $w$ drugiej połowie XVI wieku, „Rocznik Leszczyński” 1, 1976, s. 207-320.

Polaszewski L., Własność feudalna w województwie kaliskim w XVI wieku, Poznań 1976. 
Prusy Królewskie w drugiej połowie XVI wieku, oprac. M. Biskup, współpr. L. Koc, Warszawa 1961 (Atlas Historyczny Polski. Seria B: Mapy Przeglądowe, 1).

Rosin R., Wolbórz i jego okolice w XI-XVI w. Kasztelania - osadnictwo - miasto, w: 400-lecie śmierci Andrzeja Frycza Modrzewskiego. 700-lecie nadania praw miejskich Wolborzowi. Materiaty sesji popularnonaukowej z 24 IX 1972 r., red. R. Rosin, Łódź 1975, s. 11-58.

Samsonowicz H., Dtugosiodto - kariera wsi mazowieckiej w średniowieczu, „Rocznik Mazowiecki” 18, 2006, s. 32-46.

Samsonowicz H., Gospodarka $i$ społeczeństwo (XIII - poczatek XVI w.), w: Dzieje Mazowsza, t. 1, red. H. Samsonowicz, Pułtusk 2006, s. 339-394.

Samsonowicz H., Ośrodki gospodarcze w Puszczy Białej na poczattku XIX wieku, „Zeszyty Naukowe Ostrołęckiego Towarzystwa Naukowego” 6, 1992, s. 46-48.

Samsonowicz H., Wiejskość osad miejskich w późnym średniowieczu, w: Civitas \& villa. Miasto i wieś w średniowiecznej Europie środkowej, [red. C. Buśko i in.], Wrocław-Praha 2002, s. 13-16.

Skiełczyński Z., Życie umystowe w dawnym Łowiczu, „Roczniki Łowickie” 1, 2003, s. 11-40.

Stownik historyczno-geograficzny województwa płockiego $w$ średniowieczu, oprac. A. Borkiewicz-Celińska, z. 1-2, Wrocław 1980-1981, z. 3-4, Warszawa 1998-2000.

Stownik historyczno-geograficzny województwa poznańskiego $w$ średniowieczu, cz. 1, oprac. S. Chmielewski, K. Górska-Gołaska, J. Luciński, Wrocław 1982-1987.

Stownik historyczno-geograficzny ziemi chetmińskiej w średniowieczu, oprac. K. Porębska, współpr. M. Grzegorz, red. M. Biskup, Wrocław 1971.

Stownik historyczno-geograficzny ziemi warszawskiej w średniowieczu, oprac. A. Wolff, K. Pacuski, do druku przyg. M. Piber-Zbieranowska, A. Salina, red. T. Jurek, Warszawa 2013.

Stownik historyczno-geograficzny ziemi wyszogrodzkiej w średniowieczu, oprac. A. Wolff, A. Borkiewicz-Celińska, Wrocław 1971.

Sobisiak W., Rozwój latyfundium biskupstwa poznańskiego w XVI do XVIII wieku, Poznań 1960.

Stępkowski L., Bodzentyn nowożytny. Z dziejów miasta biskupiego w XVI-XVIII wieku, w: Bodzentyn. Z dziejów miasta w XII-XX wieku, red. K. Bracha, Kielce 1998, s. 81-101.

Stępkowski L., $Z$ dziejów miast opactwa wąchockiego $w$ XIII - XIX w. (do 1819 r.), w: $Z$ dziejów opactwa cystersów $w$ Wachocku. Materiaty $z$ sesji naukowej 1991 rok, red. A. Massalski, D. Olszewski, Kielce 1993, s. 23-36.

Swieżawski A., Biała Rawska w średniowieczu, „Rocznik Łódzki” 14 (17), 1970, s. $373-382$.

Szczepański J., Kolegium jezuickie w Puttusku 1566-1772, w: Dzieje Gimnazjum i Liceum im. Piotra Skargi w Puttusku, red. D. Ciok, A. Kociszewski, J. Szczepański, Ciechanów-Pułtusk 1992, s. 18-54. 
Szczepański J., Dzieje Wyszkowa i okolic, Warszawa 1998.

Szczygieł R., Lokacje miast w Polsce XVI wieku, Lublin 1989.

Szorc A., Dominium warmińskie 1243-1772. Przywilej i prawo chetmińskie na tle ustroju Warmii, Olsztyn 1990.

Tafiłowski P., Jan Easki (1456-1531), kanclerz koronny i prymas Polski, Warszawa 2007.

Topolski J., Gniezno miejscem wielkich jarmarków, w: Dzieje Gniezna, red. J. Topolski, Warszawa 1965, s. 260-324.

Topolski J., Rozwój latyfundium arcybiskupstwa gnieźnieńskiego od XVI do XVIII wieku, Poznań 1955.

Wajs H., Źródta do dziejów średniowiecznego i wczesnonowożytnego Czerwińska w zbiorach Archiwum Gtównego Akt Dawnych w Warszawie, w: Dzieje klasztoru w Czerwińsku, [red. E. Olbromski], Lublin 1997, s. 25-29.

Weiss A., Biskupstwo lubuskie, Lubusz, lubuska ziemia, w: Kapituła kolegiacka $w$ Opatowie $w$ 800-lecie istnienia, red. M. Spociński, Z. Pałubska, Opatów 2007, s. 45-59.

Województwo lubelskie w drugiej połowie XVI wieku, oprac. S. Wojciechowski, Warszawa 1966 (Atlas Historyczny Polski. Mapy Szczegółowe XVI wieku, 3).

Wroniszewski J., Szlachta ziemi sandomierskiej w średniowieczu. Zagadnienia społeczne $i$ gospodarcze, Poznań-Wrocław 2001.

Wyrobisz A., Mate miasta $w$ Polsce $w$ XVI $i$ XVII $w$., w: Miasta doby feudalnej $w$ Europie Środkowo-Wschodniej. Przemiany społeczne a uktady przestrzenne, red. A. Gieysztor, T. Rosłanowski, Warszawa 1976, s. 177-187.

Wyrobisz A., Rola miast prywatnych $w$ Polsce $w$ XVI $i$ XVII wieku, PH, t. 65, 1974, z. 1, s. $19-46$.

Zajączkowski S.M., Uwagi nad dziejami dóbr taznowskich $i$ niesutkowskich biskupstwa włocławskiego do końca XVI wieku, Łódź 2000.

Zdanek M., Dochodowość majątku klasztoru cystersów w Mogile w połowie XVI w. na podstawie inwentarza dóbr z lat 1560-1566, w: Klasztor $w$ gospodarce średniowiecznej $i$ nowożytnej, red. M. Derwich, Wrocław 2013, s. 257-273.

\section{Michał Słomski}

Network of ecclesiastical towns in the Polish Crown in the $16^{\text {th }}$ century. Introductory analysis of the issue

(Summary)

The paper focuses on the network of towns belonging to ecclesiastical institutions: bishops, monasteries, cathedral and collegiate chapters, and parish priests, located in the territory of the Polish Crown in the $16^{\text {th }}$ century. Most of these towns belonged to bishoprics and monasteries, much less to cathedral and collegiate chapters. Occasionally, parish priests owned a part of the 
town they resided in. Most ecclesiastical towns were located in Sandomierskie Voivodeship (25). No church-owned urban centres could be found in the following provinces: Pomorskie, Malborskie, Podlaskie. Ecclesiastical towns were usually middle- and small-sized, which falls in line with the general trend in the size of towns in the $16^{\text {th }}$-century Polish-Lithuanian Commonwealth. Over the course of the period, seven new towns were founded: five in bishopowned estates, one in an estate owned by a monastery and one in the property of a cathedral chapter. At the same time, there were 10 failed foundation initiatives, unsuccessful for various reasons.

The second part of the paper consists in a short description of conditions of settlement foundation. It can be observed that these were connected with the coexistence of church-owned land property. Towns were usually surrounded by at least several villages belonging to the same owner, even though there were also cases of urban centres being located far away from other settlements. The town was usually the economic and administrative centre of the property key.

All the issues touched upon in the paper should be more thoroughly analysed.

Two maps are annexed to the paper - one presents ecclesiastical property in the entire territory of the Polish Crown at the end of the $16^{\text {th }}$ century, while the other - ecclesiastical property in Greater Poland in the same period.

Michał Słomski - absolwent Instytutu Historycznego Uniwersytetu Warszawskiego, uczestnik studium doktoranckiego Instytutu Historii im. Tadeusza Manteuffla Polskiej Akademii Nauk, asystent w Zakładzie Atlasu Historycznego IH PAN. Zainteresowania badawcze: historia Kościoła w Polsce XIV-XVI w., historia gospodarcza XIV-XVI w., dyplomatyka, edytorstwo źródeł, dzieje Łowicza w XIII-XVIII w. E-mail: slomski.m@wp.pl. 